NBER WORKING PAPER SERIES

\title{
A CONCEPTUAL FRAMEWORK FOR UNDERSTANDING CRITICAL TRANSITIONS
}

\author{
Lee J. Alston \\ Marcus André Melo \\ Bernardo Mueller \\ Carlos Pereira \\ Working Paper 22144 \\ http://www.nber.org/papers/w22144 \\ NATIONAL BUREAU OF ECONOMIC RESEARCH \\ 1050 Massachusetts Avenue \\ Cambridge, MA 02138 \\ April 2016
}

This paper draws on material in Alston et al., Brazil in Transition: Beliefs, Leadership, and Institutional Change (Princeton University Press, forthcoming 2016). The larger book project got off the ground thanks to the Rockefeller Foundation hosting us as residents in Bellagio. We received valuable comments provided by the anonymous reviewers for Princeton University Press and from a book conference at Northwestern University, funded by President Schapiro at Northwestern University and Princeton University Press. Joel Mokyr and Marlous van Waijenburg organized the conference, and the participants deserve to be named: Hoyt Bleakley, Alan Dye, Joseph Ferrie, Brodwyn Fischer, Regina Grafe, Stephen Haber, David D. Haddock, Anne Hanley, Daniel Immerwahr, John Londregan, Noel Maurer, Joel Mokyr, Aldo Musacchio, Nicola Persico, Frank Safford, William Summerhill, Marlous van Waijenburg, John Wallis, and Sam Williamson. Sonja Opper kindly organized an earlier book conference at Lund University in November 2013. We thank the discussantsThomas Brambor, Christer Gunnarsson, and Carl Hampus-Lytkens-and the participants. We benefitted greatly from lengthy discussions and correspondence at critical times of our journey with Alan Dye, Thráinn Eggertsson, Avner Greif, Murat Iyigun, Douglass North, James Robinson, Ken Shepsle, John Wallis, and Barry Weingast. We thank William Summerhill for a discussion about the substance of our afterword. From a variety of people we received helpful comments on drafts: Eric Alston, Martin Andersson, Andy Baker, Robert Bates, Michael Bordo, Eric Brousseau, David Brown, Charles Calomiris, Victor Fleischer, Patrick François, 
Steven Haber, Joseph Jupille, John Londregran, Thomas Mayer, Tomas Nonnenmacher, Sonja Opper, Samuel Pessoa, Laura Randall, Hugh Rockoff, Jerome Sgard, Kenneth Shepsle, Richard Sicotte, Stefan Voigt, Steven Webb, and Eugene White. Throughout the project and for suggestions for a title we thank Robert Higgs. Presenting seminars and receiving comments at the following conferencesand universities clarified where we were going astray: Getulio Vargas Foundation; a conference at Washington University honoring Douglass North's ninetieth birthday; the Economic History Association Annual Meetings (Boston and Washington, DC); the workshop on Legal Order, the State, and Economic Development in Florence, Italy; the International Society for the New Institutional Economics Annual Meeting; and seminars at Columbia University, Indiana University, Rutgers University, University of British Columbia, University of Chicago, University of Colorado (Institutions Program and School of Law), and the University of Hamburg (Institute of Law and Economics). The views expressed herein are those of the authors and do not necessarily reflect the views of the National Bureau of Economic Research.

NBER working papers are circulated for discussion and comment purposes. They have not been peer-reviewed or been subject to the review by the NBER Board of Directors that accompanies official NBER publications.

(C) 2016 by Lee J. Alston, Marcus André Melo, Bernardo Mueller, and Carlos Pereira. All rights reserved. Short sections of text, not to exceed two paragraphs, may be quoted without explicit permission, provided that full credit, including (C) notice, is given to the source. 
A Conceptual Framework for Understanding Critical Transitions

Lee J. Alston, Marcus André Melo, Bernardo Mueller, and Carlos Pereira

NBER Working Paper No. 22144

April 2016

JEL No. N4,O10

\begin{abstract}
Critical transitions for a country are historical periods when the powerful organizations in a country shift from one set of beliefs about how institutions (the formal and informal rules of the game) will affect outcomes to a new set of beliefs. Critical transitions can lead a country toward more openness politically and economically or toward a more exclusionary society. Economic and political development is contextual; that is, there is no recipe. Periods of relative persistence are the norm with changes in institutions at the margin. We develop a framework consisting of several interconnected relatively unexplored concepts that we first define in a static context and then utilize to show how they produce a dynamic of institutional change or persistence. The key concepts include: windows of opportunity, beliefs, and leadership. Our major contribution is wedding the concepts of windows of opportunity, beliefs, and leadership to the dominant network, institutions, and economic and political outcomes to form a dynamic. We apply the framework illustratively to understand economic and political development in Argentina over the past 100 years.

Lee J. Alston

Ostrom Workshop and Department of Economics

Indiana University

513 N. Park Avenue

Bloomington, IN 47408-3895

and NBER

ljalston@indiana.edu

Marcus André Melo

Federal University of Pernambuco

marcus.melo@uol.com.br

Bernardo Mueller

Department of Economics

University of Brasilia

bmueller@unb.br

Carlos Pereira

Getulio Vargas Foundation

carlos.pereira@fgv.br
\end{abstract}


March 29, 2016

\title{
A Conceptual Framework for Understanding Critical Transitions
}

\author{
Lee J. Alston, Marcus André Melo, Bernardo Mueller, and Carlos Pereira
}

\section{Introduction}

Critical transitions for a country are historical periods when the powerful organizations in a country shift from one set of beliefs about how institutions (the formal and informal rules of the game) will affect outcomes to a new set of beliefs. Critical transitions can lead a country toward more openness politically and economically or toward a more exclusionary society. Economic and political development is contextual; that is, there is no recipe. ${ }^{1}$ Periods of relative persistence are the norm with changes in institutions at the margin. At one level, it is a puzzle that a greater number of middle-income countries have not embarked toward (or embarked toward and failed to achieve) a critical transition to higher income status, given that there are role models they could emulate. ${ }^{2}$ By emulate, we do not mean that institutions can be directly imported but only that the leaders of countries have a good idea of some of the key ingredients that today's developed societies possess: for example, rule of law; clear, secure, and impersonally enforced property rights; competent and honest bureaucracies; and open and competitive economic and political systems. ${ }^{3}$ We develop a framework consisting of several interconnected relatively unexplored concepts that we first define in a static context and then utilize to show how they

\footnotetext{
${ }^{1}$ By contextual, we mean that there are many multiple paths to sustainable development, though ultimately the extant success stories entail economic and political openness. We do not believe that it is best to first open up economically and then politically or vice versa. History has examples of either path as well as a relative balanced path between economic and political openness. Our book (Alston et al. forthcoming 2016) provides a detailed case study of Brazil from 1964 to 2014, which allows us to establish the importance of context and the heavy hand of historical institutional dependence. Our book complements and augments the recent literature on development and institutions by proposing a framework for understanding Brazilian development along with a detailed case study. In this regard, we are following in the footsteps of many: Acemoglu and Robinson (2006, 2012); Eggertsson (2005); Greif (2006, 2012); Mokyr (2009); North, Wallis, and Weingast (2009); North et al. (2012); and Schofield (2006). There are also scores of articles on institutions and development. We differ from much of the literature, which relies on historical examples of today's developed countries.

${ }^{2}$ We return to the issue of role models when we discuss leadership. Greif (2006: 195-96) recognizes the importance of role models: "Such comprehensive changes are more likely to be attempted if there is a role model, a known alternative institution with better outcomes."

${ }^{3}$ We are not arguing that there is a recipe for development. There is not; the institutions of open societies emerged out of a process of changing beliefs over time, and each country transitioned in a different way depending on their historical antecedents and political and economic endowments at the time.
} 
produce a dynamic of institutional change or persistence. ${ }^{4}$ The key concepts include: windows of opportunity, beliefs, and leadership. Our major contribution is wedding the concepts of windows of opportunity, beliefs, and leadership to the dominant network, institutions, and economic and political outcomes to form a dynamic.

\section{Understanding Critical Transitions}

Today the primary role of institutions as defining countries that are on a sustainable trajectory of economic and political openness is now widely accepted in the literature (North, Wallis, and Weingast 2009; Acemoglu and Robinson 2012; inter alia). By sustainable development, we mean that economic growth is seldom negative and there is relatively little fluctuation in growth rates; this coupled with political development of real competition in elections in which ex ante the outcome is not known, the process is transparent, and ex post society accepts the outcome without violence. ${ }^{5}$ But, though we know the differences in institutions between the most developed and the rest, we do not have a recipe for countries on how to make the critical transition from less open to more open economic and political institutions. We have analytical narratives on how the pioneer countries like France, the United Kingdom, and the United States made their transitions. ${ }^{6}$ But, the developmental paths of these countries differed even though they ended up with more or less the same set of institutions. In short, transitional paths are contextual, and institutional change is embedded in different belief structures that define and limit the feasible set of institutions that any country can implement at a certain time. But, if beliefs define and limit institutional changes, what changes beliefs in ways that allow a country to embark on a new trajectory? In our framework, when economic and political outcomes differ from expectations, it creates a window of opportunity for changing institutions. Beliefs about the relationship between institutions and outcomes held by some organizations in the dominant

\footnotetext{
${ }^{4}$ Eggertsson (2005) analyzes the factors that can account for "imperfect institutions," by which he means that actors are aware of alternative institutions that would produce more economic growth. He lays the major blame on social models. We will return to this in our section on beliefs. Eggertsson (2005: 151), Greif (2006), and Schofield (2006) are closest to us in arguing that experience and shocks shape beliefs/mental models.

${ }^{5}$ Of course, other attributes are also important and are captured in the term "open access" as used by North, Wallis, and Weingast (2009).

${ }^{6}$ North et al. (2012) present an analysis of the developmental paths of countries that have not yet transitioned (with the possible exceptions of Chile and South Korea). The paths taken by all countries vary enormously.
} 
network become malleable. Moreover, this malleability creates an opportunity for leadership to coordinate institutional change. Why? Because beliefs about how the world works change when outcomes deviate from expectations. In such situations, coordination among the dominant organizations in society is critical for moving to a new trajectory because the dominant organizations may differ in their beliefs on how to change or maintain institutions to get desired outcomes. The dominant network may become fragile and porous, and leadership during such windows of opportunities could be decisive for whether a country embarks on a new path and, moreover, whether it can stay on the path. ${ }^{7}$ It is one thing to "give it a go" and quite another to stick to it.

Our framework enables us to understand the fundamental transition that has been underway in Brazil from a closed, corrupt, clientelistic society to one that is driven by a belief in fiscally sound social inclusion, which has significantly decreased inequality and promoted democratic stability over the past twenty years (Alston et al. forthcoming 2016). ${ }^{8}$ Generally, social inclusion ends up in populism with too few restraints on government spending. This was Brazil from 1985 to 1994. On the other hand, fiscally sound policies alone, for example, the "Washington Consensus," are not politically sustainable in a democracy that has not yet transitioned to developed country status. Brazil embarked on its transition toward a more sustainable developmental path by wedding social inclusion with orthodox monetary and fiscal policies. The hallmarks of making the transition include: (1) the organizations in society agree to play by the rules, (2) politics are open and competitive, (3) macroeconomic stability as well as social inclusion dominate decision making, and (4) the state should play a significant role in ensuring the playing field becomes more level. This set of beliefs has driven institutional change in Brazil since 1994.

\footnotetext{
${ }^{7}$ Our use of the terms "organization” and particularly "dominant network" builds on the work of Wallis (2016), whose purpose differs from our analysis. Wallis is interested in explaining the existence of government(s) and the role of impersonal rules.

${ }^{8}$ Given the current economic and political turmoil in Brazil over the past year, this may seem like an outrageous claim, but so far the participants, though pursuing corruption and impeachment of the president, have been playing by the rules. There is little violence, no serious talk of military involvement, and, for the most part, peaceful protests. To the extent that there are altercations, they are between PT supporters of the president and the supporters favoring impeachment and pursuing corruption. The decline in the economy is the result of a sharp reduction in commodity prices coupled with some flight due to the Petrobrás scandal. All commodity-dominant countries have faced downturns, and the degree of the downturn has been dampened (Australia and Canada) or exacerbated by domestic politics (Brazil and Russia).
} 


\section{How Does Our Framework Fit in the Literature?}

The framework presented here aids our understanding of developmental outcomes in general. Our framework relies on windows of opportunity as a crucial part of its dynamics. Although endogenous incremental change is an important part of the dynamics, so too are relatively abrupt endogenous or exogenous shocks. Equally important, continual supporting institutional changes must follow in the wake of the window of opportunity in order to buttress the new beliefs and maintain the society on the road to sustainable development. ${ }^{9}$

Compared to the pioneer countries that have transitioned to open societies, there is a greater comprehension today of what is going on and a wider offering of tried and tested institutional alternatives. To stress this difference, we use the term "window of opportunity” rather than "critical junctures" to refer to the shocks that initiate a process of change. ${ }^{10}$ Although the difference may appear subtle, "window of opportunity” implies that there is a role for leaders to purposefully react to the new circumstances to change institutions by coordinating other organizations in the dominant network to a focal core belief, which forms an umbrella over institutions. ${ }^{11}$ In addition, most decision makers in the past acted to solve current problems without seeing that solving a particular problem (e.g., corruption in banking in the nineteenthcentury United States) could have downstream positive (or negative) effects. In our framework, leaders are both backward looking (in the sense of solving a current problem) and forward looking - they can foresee (never perfectly) downstream consequences. ${ }^{12}$ We view the inability to foresee downstream events not as probabilistic but in terms of uncertainty in the way that Frank Knight viewed uncertainty; that is, the downstream consequences are unknowable (Knight 1921).

\footnotetext{
${ }^{9}$ Our focus on the importance of repeated supporting institutional changes has much in common with the formal model of Bidner and François (2013), who stress the role of repeated virtuous actions by leaders in order to transition to a democracy. We come back to this point in our sections on beliefs and leadership.

${ }^{10}$ Acemoglu and Robinson (2012) use the term "critical juncture" to describe a discrete change in a country's trajectory.

${ }^{11}$ On core beliefs, see Greif (2006) and Schofield (2006).

${ }^{12}$ Eggertsson (2005), Greif (2006), and North, Wallis, and Weingast (2009) are closest to our concept of window of opportunity in that the process is not a "big bang" and must be sustained over a period of time sufficiently long to affect beliefs in the general population about how the "new" world works. We differ in our stress on the forward-looking ability of today's decision makers because of the role models played by the pioneer countries.
} 
A critical juncture, on the other hand, conveys the notion of a shock in the more distant past to which rulers and citizens reacted with less understanding of all that was involved and a weaker notion of what could possibly be done. This does not mean that windows of opportunity will always be seized or that they will lead to sustained development, as leadership may be absent or the dominant network is such that growth-enhancing change is blocked. Also, whereas it is relatively easy to look back at history and recognize a critical juncture, it is not straightforward to sort out which of the myriad events in a country’s current life are consequential and may turn out to be realized windows of opportunity, and which are just full of sound and fury but will signify nothing tomorrow. The difference is the combination of a decisive action taken at time $t$ when the window is recognized and the necessary downstream supporting institutional changes taken to affect outcomes and in turn beliefs. All societies face numerous windows of opportunity, some big and some small, and most are not seized. As social scientists, we can look back and identify missed windows of opportunity. ${ }^{13}$

Given that windows of opportunity are a chance that can be seized, who will do the seizing? In many instances, realizing the opportunity requires leadership to perceive the situation, propose what must be done, coordinate the effort, and persuade the dominant network to take the leap of faith. Many windows of opportunity go by undetected or unrealized because of a lack of leadership (which might be an individual or a group) to provide the necessary elements of change. The role of leaders is typically absent in the literature on institutions and political science, but is often overplayed by historians and business/public administration scholars. ${ }^{14}$ We see a circumscribed, yet often crucial, role for leaders as the catalysts during windows of opportunity.

\footnotetext{
${ }^{13}$ In the empirical sections of our book, we highlight examples of missed windows of opportunity for Brazil (Alston et. al. forthcoming 2016).

${ }^{14}$ Peele (2005) argues that there is a big, but not insuperable, hiatus separating leadership studies from political science; whereas the former explicitly attempts to identify personal qualities that individuals possess and how they deploy those skills in a particular context and situation, the latter mostly derives explanatory power from the analysis of political structures and institutions, thus marginally exploring the difference made by key political actors. Peele (2005: 188) states, "For those who study leadershipwhether it is political leadership or leadership in some other organizational or societal environment such as a school, a company or a gang-the specific way the leaders interact with their followers is what needs to be isolated. The exploitation and strategic use of authority in a range of different settings by individuals or elites is a necessary building block to understanding. But it is not the whole story; and approaches to leadership like approaches to politics reflect the intellectual and social environment of their times." We differ from Peele in that our leaders do not so much have "followers," but instead coordinate the dominant network to a new core belief. More on this below.
} 
The final distinguishing characteristic of our framework is the central role played by beliefs in the dynamics between institutions and outcomes. A central question in the literature on institutions has always been why all countries don't put in place good institutions given that they are widely recognized as the key to long-term growth. The standard answer is: new institutions have redistributive consequences that cannot be renegotiated owing to transaction costs and commitment problems, such that those in the dominant network prefer to block change and retain a larger expected share of a smaller pie. Such social conflict issues are essential for understanding the process of development. However, this explanation requires that all economic agents calculate the impact of each set of new institutions and rationally pick the ones that maximize the discounted present value of the inherent rental streams. In the absence of such unrealistic powers of rationality, beliefs arise out of the need to interpret the way the world works. When assessing whether to pursue or block changes in institutions, those in power have a rough map in their heads of how each set of institutions leads to different outcomes. Beliefs are those maps or instructions, though they lack the specifics of a technical manual. They provide an interpretation of cause and effect between how different institutions translate into economic and political outcomes. If the world were such that those maps varied little across different groups and circumstances, and that beliefs had a natural tendency to reflect reality very closely (when there even is a "true" relationship between institutions and outcomes), then beliefs would not be very consequential. However, the diversity of human experience shows that interpretation of how the world works has varied dramatically across societies, so that understanding why particular institutions have emerged and persisted in specific countries requires careful and explicit attempts at understanding the country-specific core beliefs of those who are in power. In many societies, there is not a widely held consensus across all organizations on core beliefs. But what matters for the establishment of formal institutions are the core beliefs of those in power. Whether these become a consensus depends in large part on the outcomes that the institutions produce; for example, in democracies, if the institutions produce outcomes that benefit more organizations, they will gravitate toward the belief of those in power. Even in autocratic societies, many organizations may not like the outcomes, but those in power have the ability to maintain the formal institutions and dominant organizations in society so that other marginalized organizations and citizens at large realize that "this is how their world works." 


\section{The Building Blocks of Our Conceptual Framework}

\section{Windows of Opportunity}

Windows of opportunity are historical occasions when there is a chance to change the trajectory of a country's economic and political outcomes by changing beliefs and institutions. We stress that windows of opportunity are not just decisive moments, but rather a series beginning with an opportunity and ending with a change in the dominant core belief held by the dominant network and most citizens. Windows of opportunity begin when (1) the rental streams fall short, or exceed the expectations of members of the dominant network; (2) a new member or organization enters the configuration of power because of an unanticipated economic or political shock; and (3) the beliefs of some members in the dominant network change either because of the change in the economic and political outcomes or because of an exogenous event. ${ }^{15}$ All crises are windows of opportunity, but windows of opportunity do not require a crisis. ${ }^{16}$ There are undoubtedly many windows of opportunity, but it is the interaction among windows of opportunity, beliefs, and leadership that matters. Windows of opportunity are not only “windows” for changing institutions; they are windows through which leaders can initiate a transition toward a society that is more or less open, economically or politically. ${ }^{17}$

\section{Dominant Network}

In our framework, political power means the ability to change formal institutions (e.g., the laws of a society), and during windows of opportunity, the potential to influence changes in beliefs. In

\footnotetext{
${ }^{15}$ For example, the financial crisis of 2008 and its aftermath has affected the beliefs of many actors in the sanctity of the existing relative prices of securities or housing to reflect long-run values. In short, many (but not all) economists now believe that bubbles can and do happen. This is no surprise to economic historians, several of whom have stressed financial bubbles (see, in particular, Aliber and Kindleberger 2015; Neal 1993).

${ }^{16}$ The window of opportunity may be open for some time and awaiting a leader to seize the moment. This was the case of hyperinflation in Brazil, which exceeded 100 percent/year from 1980 until 1995, peaking at more than 30,000 percent in 1990. Cardoso seized the window of opportunity in 1994 and, as a result, started a transition to a new belief in fiscally sound social inclusion. This also appears to have been the case in the dramatic changes in institutions put in place by President Rafael Correa in Ecuador. Bidner and François (2013) similarly do not rely on a crisis for a transition to democracy to begin. See Higgs (1987) for a convincing discussion of the important role of crises in the United States prompting and sustaining the growth of government.

${ }^{17}$ The emphasis here is on a transition path toward sustainable development. This concept of a window of opportunity is consistent with Eggertsson (2005: 151): “opportunities for reform are created by real factors that upset the political balance, by real shocks and exogenous impulses that induce actors to revise their models.”
} 
Figure 1, we show how the nature of the dominant network becomes more complex as development progresses. Panel A depicts an early stage of development, when there are few organizations (X, Y, and Z) headed by elites (superscript E) and their clients (superscript C). ${ }^{18}$ The elites in each organization possess some form of violence potential that they use to control their clients and possibly to appropriate wealth from other organizations. A group of kingdoms is an example of this scenario.

(Figure 1 about here)

The potential for increased productivity and economic gain from peace might prompt the organizations to establish a pact where each refrains from violence. The dotted line demarcates the dominant network formed by the elites across organizations. By refraining from violence, each is able to reap greater rents than would accrue when violence was endemic. The dominant network is an adherent organization that will function only as long as the rents make compliance incentive compatible. Each individual organization, on the other hand, is a contractual organization that benefits from the third-party enforcement provided by the dominant network, making it easier for each organization to control its own clients. The third-party enforcement also allows for anonymous exchange among members of different organizations. The gains in specialization and productivity that can be achieved are limited, however, by the fact that the creation of rents, which keeps the dominant network together, requires entry into economic and political markets to be restricted. The barriers to creation of new organizations restrict investment and innovation with deleterious consequences for long-term economic growth. Furthermore, periods of peace and cooperation are often precarious, as shocks that change the violence potential of any of the organizations may cause peace to break down until a new network can be formed through a new configuration of rents. Many countries remain endlessly stuck in cycles of this nature in what North, Wallis, and Weingast (2009) term a limited access society.

While some countries have been able to achieve considerable progress under limited access, historical experience suggests that there is a limit to how much growth can be achieved

\footnotetext{
${ }^{18}$ Panel A is an adaptation and extension of figure 1 in Wallis (2011). We also borrow some terms, such as "violence specialists" and "adherent and contractual organizations," from Wallis (2011). We borrow the term "dominant network" from Wallis (2016). Network, rather than coalition, stresses the multitude of relationships among those in the network. Not all the members of the network are directly connected, but they have a stake in sustaining the network to sustain their rents.
} 
under such arrangements. A few countries, however, are able to develop an increasingly complex social organization that expands access into a dominant network, allowing for even further specialization and trade. This situation is represented in panel B of Figure 1. Note that not only have new (economic, political, religious, and educational) organizations emerged, including a central government, but access to the rents in each organization has become more widespread.

While in panel A the proportion of the population that is in the elite (parameters $\varepsilon, \eta$, and $\pi$ ) is extremely small, in panel B greater numbers have been granted access to rents and to the creation of new organizations. This incorporation can take place as a strategic decision by the current dominant network during times of upheaval as a means to preempt unrest and revolution (as in Acemoglu and Robinson 2000, 2006). Alternatively, greater access may take place when the creation of new organizations increases productivity and growth in ways that expand the rents that the current dominant network appropriates (as in North, Wallis, and Weingast 2009). In this process, the rule of law and impersonal exchange may emerge within the elite network, creating a society where rents and privilege, while still present, are increasingly dissipated by economic and political competition among this extended dominant network. ${ }^{19}$

As development proceeds, the plethora of organizations "at the table” increases, which in turn expands the dominant network. Organizations in the dominant network may include political, economic, social, or religious organizations. We are not concerned with the factors determining what is in an organization's “interest” but simply that some organizations have power and others do not; power is a matter of the access to influence or shape institutions. ${ }^{20}$

In functioning democracies, citizens also matter because they vote. Politicians listen to public opinion because disregarding it could mean being voted out of office. All these forces combine to produce a de jure and de facto configuration of political power. It is this set of organizations and their relative power that defines and enforces the formal institutions in a society. The institutions in a society are shaped by those in the dominant network (and their beliefs, which we come to shortly) and their preferences, that is, the outcomes that they would like to see; but there is uncertainty about the precise impact of institutions on outcomes. The

\footnotetext{
${ }^{19}$ Brazil is at this stage in the development process. By granting open access to the creation of new organizations to increasing proportions of its population, Brazil has created circumstances for the Schumpeterian process of creative destruction that underlie the growth trajectory of most developed nations.

${ }^{20}$ Wallis (2011) argues cogently that preferences, the range of choices, relative prices, and beliefs determine "interests."
} 
organizations differ in their beliefs about the cause-and-effect relationships between institutions and economic and political outcomes. It is the beliefs of the organizations in the dominant network, rather than their preferences, that ultimately constrain and shape the institutions of societies.

\section{Beliefs}

By beliefs, we follow North (2005), who defines them as the subjective views of actors about the way the world works. Beliefs are very different from preferences, which are views about what organizations would like to see transpire, whereas beliefs are about perceived outcomes from institutional change or maintenance, though, because the world is non-ergodic, there will also be some degree of unintended consequences. In equilibrium, institutions are consistent with beliefs. But, we are most interested in beliefs during windows of opportunity. Most of the time, societies operate on a "core” set of beliefs, but during “constitutional quandaries," core beliefs become fragile (Schofield 2006). It is the fragile moments that enable societies to change their trajectories.

Ultimately, beliefs about how the world works will shape the institutions that those leaders/organizations implement to achieve a desired, expected set of political and economic outcomes. ${ }^{21}$ But it is not obvious which institutions will lead to the outcomes they want, given the constraint of beliefs about how others will act. This is important in the transition from one set of core beliefs to another. If there were some comprehensive manual mapping institutions to outcomes, those in the dominant network could look it up and see exactly which institutions they need to put in place to get the outcomes they want. But there is no manual; there is uncertainty about how things work and about the causal mechanisms between institutions and outcomes. As shown in Figure 2, a given set of institutions can lead to many different expected political and economic outcomes. The outcomes, which are expected to emerge from a given set of institutions, will depend on the beliefs of how institutions affect outcomes.

(Figure 2 about here)

For the leader(s)/organizations in power, formal institutions are a choice variable during windows of opportunities, although the choice process is quite complex. In addition, during some

\footnotetext{
${ }^{21}$ This is consistent with Greif's definition of “internalized beliefs.” He argues that internalized beliefs of those with power can motivate them to change institutions consistent with their beliefs.
} 
windows of opportunity, beliefs can also be somewhat endogenous to those in power. It depends on the size of the window of opportunity and the fragility of the ex ante beliefs. Figure 3 shows the full set of expected outcomes that can emerge from the full set of conceivable institutions.

(Figure 3 about here)

There are $j=1, \ldots J$ possible set of institutions, $k=1, \ldots K$ different sets of beliefs, and expected outcomes $x_{k j}$ for each combination of institutions and beliefs. If it were clear how the world worked, then it would be easy to choose the institutions that lead to the best outcomes. But given the uncertainty, it is not clear which branch $b^{k}$ society is on. So, those in power need some way to map — even though always imperfectly — from institutions to outcomes. Institutions shape choices that people make because they influence incentives. But, formal institutions are not the only influence on the choices that people make that determine outcomes. In addition to the unintended consequences from changing formal institutions, there are unintended consequences from informal institutions; and internal and external shocks, which all play a role in the ultimate outcomes.

Beliefs emerge from history, experience, interaction, and serendipity, though those in power have a greater scope to act on their beliefs. ${ }^{22}$ Once beliefs emerge, the choice in institutions becomes tractable. Given belief $b^{k}$ emerges, the group in power will choose Institutions $^{j}$, where $j$ is the set of institutions that leads to the best expected outcome for them. If, for example, given beliefs $b^{3}, E$ (outcomes ${ }_{3}^{3}$ ) $>E$ (outcomes ${ }^{3}$ ) for every $i \neq 3$, then in Figure 4 institutions $j=3$ would be chosen as they maximize the expected outcomes for the group in power. We stress that institutions never map directly into outcomes, but rather those in power can choose the institutions that they believe will give the best expected outcomes.

(Figure 4 about here)

Once those leaders/organizations with power choose and implement institutions, the outcomes that emerge have to match their expectations at least approximately; otherwise, the divergent outcomes will change the organizations in the dominant network, or the beliefs of those in the dominant network, or both. The degree to which new formal institutions change outcomes depends on the extent to which they are compatible with the beliefs and norms of the

\footnotetext{
${ }^{22}$ When outcomes are very different from expectations, beliefs change, at least for those in power, and a window of opportunity emerges for leadership. Schofield (2006) argues that Benjamin Franklin, acting on news that the French would support the colonies in their independence struggle with Great Britain, convinced the elite in the colonies to draft and sign the Declaration of Independence.
} 
economic and political organizations in society. If the beliefs of a sufficient number of organizations are firmly held and are inconsistent with the new incentives, the expected outcome for those in power will not materialize. The incompatibility of possible new institutions with the extant beliefs held by actors at large is a significant part of the explanation for institutional persistence (Greif 2006). This is persuasive; however, if beliefs are malleable during windows of opportunity, institutions will have a bigger impact on outcomes because behavioral beliefs by organizations outside the dominant network may also change with repeated behavior and institutional deepening. ${ }^{23}$

When expected outcomes do not materialize, there will eventually be a revision of the beliefs of those in the dominant network, or the dissatisfaction with the outcomes might, given a window of opportunity, lead to a punctuated change in the dominant network, beliefs, and institutions. We argue that experiences (political and economic outcomes) are the main factor shaping and changing beliefs of leaders/organizations in the dominant network as well as shaping the beliefs of citizens at large. ${ }^{24}$

We are not proposing a full theory of the determinants of beliefs. Our goal is more modest. Like North, Wallis, and Weingast (2009: 262), we argue that "the cultural environment—-the political, economic, social context—fundamentally influences beliefs.” It is the beliefs of those in the dominant network that matter because those in power face windows of opportunity and make the formal institutions (laws). Nevertheless, the beliefs of citizens do matter in many countries. Indeed, the beliefs held by the citizens are a constraint on those in power. Those in power have preferences over outcomes, but it is their beliefs that determine their actions. Our view on the role of beliefs matches Mokyr's view of the role of enlightenment in enabling the British Industrial Revolution:

To sum up: Britain became the leader of the Industrial Revolution ... thanks to the great synergy of the Enlightenment: the combination of the Baconian program in useful knowledge and the recognition that better institutions created better incentives. (Mokyr 2009: 122)

\footnotetext{
${ }^{23}$ Repeated play by the dominant network is what drives changes in beliefs by citizens about the actions (and motives) of those in power. Repeat play is at the heart of the model in Bidner and François (2013).

${ }^{24}$ Our view is very similar to Eggertsson's (2005: 26) definition of a policy model: "Policy models are the operational models that guide decision makers, whether in the private or public sphere. Policy models define for the actor his or her choice set, rank the elements in the choice set, and describe relationships between means and ends (instruments and targets)."
} 
According to Mokyr (2009: 40), “Enlightenment beliefs followed in the footsteps of Bacon’s idea of understanding nature in order to control her." It was a belief that with the application of useful knowledge, a country could progress over the status quo. The application of knowledge in turn needed institutions that promoted "progress." At the time, this was a new belief as well as a belief not shared by all powerful actors. It is the very nature of subjectivity of beliefs that gives rise to different views about the impact of institutions on outcomes. For a modern example, following the financial crisis of 2008, there is a lively debate among economists, politicians, and other interest groups about the impact of a stimulus plan versus an austerity plan for promoting recovery. ${ }^{25}$ The actions that get taken result from the relative power of the organizations in the dominant network and beliefs of those with the power, as well as the role of leadership.

An even more forceful account of the centrality of beliefs for promoting prosperity comes from Deidre McCloskey in her two volumes: Bourgeois Virtues (2006) and Bourgeois Dignity (2010). ${ }^{26}$ McCloskey views “ideas” and not institutions, geography, natural resources, or other determinants as the catalyst of modern economic growth starting in Europe in the mid-eighteenth century. In particular, the idea that started the "Great Enrichment” was the change in the belief about the dignity of commercial pursuits. Once commercial and mercantile activities stopped being viewed with contempt and dishonor-as opposed to the pursuits of warriors, noblemen, and the clergy — trade, commerce, exchange, and innovation flourished, unleashing the unprecedented explosion of prosperity. ${ }^{27}$

In today’s modern world, political and economic actors can have a more forward-looking view of beliefs because there are role models. Whereas the pioneer countries were trying to solve problems in light of their past experiences, today's countries can draw on the experiences of the already-developed world for some of their beliefs. Not only can those in power draw from these experiences, but in some instances they do so inappropriately for a particular country. This was

\footnotetext{
${ }^{25}$ This is written in 2016 in the shadow of the "euro crisis" and still persistent high unemployment across many countries in Europe.

${ }^{26}$ Obviously, the locus classicus for the notion that ideas matter is Max Weber's work. Hall (1989) provides a more recent treatment of the role of ideas in economic policy making.

${ }^{27}$ Although we share McCloskey's position on the centrality of ideas/beliefs in economic growth and development, we do not go as far as she does in downplaying the role of institutions. In our framework, beliefs are important because they affect which institutions get put in place, and, by affecting outcomes, institutions feed back into beliefs. For this reason, it makes little sense to argue whether institutions or beliefs matter the most: they are both crucial parts of the dynamics.
} 
the problem with blindly relying on the "Washington Consensus." ${ }^{28}$ The failure of the consensus to work in certain countries was a result of the incompatibility of the rules/incentives with the beliefs held by citizens. We stress that learning from other countries does not mean that the implementation will have the same effect, but nevertheless, it can affect not only their "belief" but the depth of their belief, which determines how long those in the dominant network hold on to the cause-and-effect relationship. For example, if those in power want to control inflation, there is a consensus among many analysts that this is easier to accomplish if the central bank has independence from political pressure. So far, we have simply posited that beliefs shape actions; but if beliefs shape institutions, it is paramount to posit how beliefs change, at least on the margin. We will do so later when we discuss the dynamics of the framework. For now, we posit that belief deepening depends on outcomes and the actions taken by others, including the support of citizens. ${ }^{29}$ Belief deepening is also iterative between the institutions established by those in power and the perception of the outcomes by organizations and citizens. ${ }^{30}$

\section{Leadership}

Leadership is a relatively absent concept in most frameworks of institutional change, though its importance has seen resurgence. ${ }^{31}$ By leadership, we mean that certain individuals at certain

\footnotetext{
${ }^{28}$ On the incentive compatibility problem of policy advice, see Acemoglu and Robinson (2013).

${ }^{29}$ For examples of how belief deepening depends on the outcomes being consistent with the prediction of those in power, who first held the belief, see Bates, de Figueiredo, and Weingast (1998), who examine Zambia and the former Yugoslavia; Eggertsson (2005), who analyzes the persistence and eventual change in beliefs in Iceland; Rakove, Rutten, and Weingast (2004), who examine beliefs in the colonies leading to the Revolutionary War between the North American colonies (United States) and Great Britain; and Greif (2006), who examines beliefs in the context of medieval trade.

${ }^{30}$ On the importance of the dynamics for belief deepening, we are consistent with Bidner and François (2013).

${ }^{31}$ We thank Avner Greif, Patrick François, and Barry Weingast for discussions on the roles of leadership and beliefs. For an excellent analytical survey of recent contributions to the literature on leadership, see Ahlquist and Levi (2011). As examples of the resurgent importance of leadership in frameworks of institutional change, see Bidner and François (2013), who model the interaction of leaders and citizens in transitioning to democracy; Greif (2006: 201-2), who discusses the importance of "institutional entrepreneurs"; Jones and Olken (2005), who use deaths of leaders as an exogenous change in leadership and find that leaders matter for economic growth; and Schofield (2006), who argues that during “constitutional quandaries" leaders can influence the shift to a new core belief. Schofield posits that Benjamin Franklin, James Madison, Thomas Jefferson, Abraham Lincoln, and Lyndon Johnson were "architects of change" (leaders). Earlier scholars recognizing the importance of leadership include Harberger (1998), who strongly argues that leadership mattered enormously for the economic reforms in Latin America; and Higgs (1987) and North (1981), who discuss “ideological entrepreneurs” (for Higgs in times of crisis). Leadership has been recognized by the "Austrian" school as entrepreneurship, but for
} 
moments in a country's history make a difference because of their actions. The counterfactual situation is that if someone else or another group of people were in the same position of power with the same beliefs, the forthcoming institutions could have been different. ${ }^{32}$ Our view is akin to the "structural theories" of leadership and most similar to leadership as espoused by Schofield (2006). Ahlquist and Levi cogently describe Schofield's concept of leadership:

For Schofield, pivotal moments in history — what he calls “constitutional quandaries”occur when core beliefs no longer conform to reality or, slightly more formally, when there is extreme variation in individual assessments of the appropriate action relative to the common, shared understanding. When these moments occur, small shifts in the beliefs of a few may trigger a cascade that results in an entirely different configuration of beliefs.

A leader is the agent most likely to trigger such a cascade. According to Schofield, "architects of change" must do two things: (a) communicate a model of the world in which there are specific outcomes associated with differing courses of action and (b) convincingly advocate a specific outcome. (Ahlquist and Levi 2011: 8)

We differ from Schofield in that we do not believe that beliefs change in a "cascade” but rather deepen, depending on outcomes consistent with the beliefs initially held by a "few." We agree that leaders start the process because they hold beliefs about institutional changes that can set the country on a new trajectory. This change in trajectory is just a start and must be reinforced over time. We are not arguing that leaders simply impose beliefs from the top down but rather leaders sense, articulate and convince others of the new belief. Not mutually exclusive is the view that the belief is latently held by many.

As noted in chapter 2 of Alston et al. (forthcoming 2016), the fact that history is replete with the mention of individuals lends considerable anecdotal weight and circumstantial evidence to the argument that certain individuals did make a difference. Leadership comprises several concepts that are not mutually exclusive: (1) cognition, (2) heresthetics or coordination, (3)

the most part has been applied to business organizations, not political organizations. See Wagner (1966) and Frohlich, Oppenheimer, and Young (1971) for a role for political entrepreneurship. Political scientists have elaborated on leadership, but mostly in the context of principal/agent models. See Fiorina and Shepsle (1989) for a discussion of formal theories of leadership in which they discuss the strengths and weaknesses of principal/agent models. For an earlier discussion of the coordinative role of leadership, see Neustadt (1990) and Riker $(1983,1996)$. We draw most heavily on Ahlquist and Levi (2011), Greif (2006), Riker (1996), and Schofield (2006).

${ }^{32}$ Ellis (2015) maintains that "The Quartet” of Washington, Jay, Hamilton, and Madison were critical in transitioning the US states into a nation. 
adaptability, (4) imagination, and (5) moral authority. ${ }^{33}$ Before one can be a leader, she has to cognitively be aware that a window of opportunity exists. In addition, that person must know how to take advantage of the window of opportunity. In short, cognition entails being able to address two questions: What is the problem or opportunity that we face? How can we solve the problem or take advantage of the situation? This should not be construed that leaders perfectly foresee all downstream consequences, but only that they see the problem and have a provisional "game plan" on how to both correct the problem at time $t$ and understand that they will have to react to downstream consequences in unforeseen ways to sustain the solution to the problem at time $t+n$. Reacting to downstream consequences requires adaptability. ${ }^{34}$ Indeed, without downstream institutional deepening, the initial "big bang” would not produce long-run benefits. It is the combination of the initial institutional change that, if successful, affects beliefs in a way that will enable later institutional deepening. Leaders also never act alone; it is the orchestration of other powerful organizations in the dominant network that allows the initial change and subsequent institutional deepening to take place. Another way of putting it is: if the initial institutional changes produce outcomes that benefit extant organizations or create new organizations that win, the beneficiary organizations now have a stake in sustaining and deepening the new institutions.

Political entrepreneurship to overcome the collective-action problem is another way to portray leadership (Wagner 1966). We refer to political entrepreneurship, following William Riker (1996: 9), as heresthetics, which Riker defined as: "the art of setting up situationscomposing the alternatives among which political actors must choose-in such a way that even those who do not wish to do so are compelled by the structure of the situation to support the heresthetician's purpose.” Heresthetics involves strategy, especially dynamically in the course of decision making. ${ }^{35}$ There are two aspects of "dynamic": (1) the art of compromise in the interest of getting most of what you want and (2) staying the course temporally in order to solidify beliefs. Heresthetics is the "art" of policy making and is not justified by ex post rational choice and could certainly not be designed ex ante by a mechanism design approach. Successful

\footnotetext{
${ }^{33}$ See Greif (2012, esp. chap. 3) for the leadership roles of cognition, moral authority, and coordination.

${ }^{34}$ Knowing ex ante that there will be unforeseen consequences that need to be met is consistent with what North (1990) called "adaptive efficiency."

${ }^{35}$ Riker $(1983,1996)$ applied heresthetics to the establishment of the electoral college and the ratification of the US Constitution.
} 
leadership entails cognitive ability of knowing what to do along with the coordinative ability of getting others in power to go along.

Leadership frequently entails imagination, that is, making an off-the-path move that no one could have anticipated, though it carries the day. ${ }^{36}$ In a sense, imagination entails seeing further down the game tree than others in the dominant network. Hamilton is an excellent case of a leader with imagination. In January 1786, the confederacy agreed to meet in Annapolis in September of 1786 to discuss revising an article pertaining to interstate trade. The meeting was a non-starter because only five states showed up and you needed unanimity to amend an article. In a final meeting of the delegates, Hamilton rose and

claimed there was unanimous support within the Annapolis delegation for "a future Convention" with a roving mandate to address all the most salient issues, scheduled to meet in Philadelphia on the second Sunday in May 1787. ... It was as if a prizefighter, having just been knocked out by a journeyman boxer, declared his intention to challenge the heavyweight champion of the world. (Quoted from Ellis 2015: 100)

Against all odds, thanks to careful planning by Madison in particular, all states save Rhode Island sent delegations to Philadelphia.

Leadership can be in leaders' and their supporters' narrowly construed self-interest, but leaders at times take reputation or "moral" rents into account (Greif 2008). Some leaders try to do "the right thing” for their country by "playing for the history books." Harberger (1998) maintains that several Latin American leaders from the 1960s to the 1990s took courageous steps to help their economies with unselfish motives driving them. In addition to seeking "moral" rents, some leaders have moral authority either because of their past or because they earned it. Moral authority does not necessarily make heads of state "leaders" but it gives them legitimacy, which in turn can induce a public to trust their motives, which may lead more readily to accepting new beliefs during windows of opportunity. ${ }^{37}$

Leadership can change the trajectory of a society for better or worse. Leadership is an important concept only when there are windows of opportunity. For much of the time, countries

\footnotetext{
${ }^{36}$ We thank Ken Shepsle for insights during conversations. Imagination plays an important role in Shepsle (2016).

${ }^{37}$ Because of leading the Revolutionary War, George Washington earned moral authority that crucially helped Hamilton, Jay, and Madison to push for nationhood on which the United States embarked with the Constitution and the Bill of Rights (Ellis 2015). Nelson Mandela in South Africa or Václav Havel in the Czech Republic commanded moral authority because of their time spent in prison. On the use of parliament for legitimacy of kings in England, see Greif and Ruben (2014).
} 
are on "autopilot," such that the rental streams are within a tolerable band for those in power so that there is no reason to rock the boat by changing institutions in a big way. It is not the case that all you need for development are "great" leaders but rather that individuals and certain organizations during windows of opportunity made a difference. For example, if this were not the case, there would be no need to discuss France without Napoleon; the United States without George Washington; Great Britain absent Churchill; China after Mao and with Deng; Argentina after Perón; or Brazil after Cardoso. We believe that these individuals, along with their allies, made a difference. Similarly, today there are discussions about Cuba after Castro; Korea after Kim Jong I; and Egypt after Mubarak. If individuals did not matter, then these discussions would be pointless. $^{38}$

\section{Institutions}

We follow in the now standard tradition of North (1990) by defining institutions as the formal and informal "rules of the game," along with enforcement for noncompliance, that shape behavior. Formal institutions include the laws of society and how they are enforced. Informal institutions include the norms of behavior within a society. A critical difference between formal rules/laws and norms is enforcement. Formal rules mean that there are recognized formal sanctions, even if only in a probabilistic sense. Norms do not have a specified enforcer but are typically enforced through some form of societal sanction, ostracism being such a form. The sanctions emanate from the shared belief by most members of society in the norm. ${ }^{39}$ In legitimate democracies with checks and balances, laws are passed under the shadow of the Supreme Court. ${ }^{40}$ Together, formal rules/laws and informal norms provide the incentive structure for economic, political, and social actions. By the incentive structure, we mean the perceived reward structure faced by all individuals in political activity, in market activities, and within firms and other internal organizations. The perceived rewards vary enormously across

\footnotetext{
${ }^{38}$ We recognize that the exit of certain individuals may simply be a tipping point and that many other underlying economic and political organizations may have already changed. This appears to be the case for Cuba, which has now embarked on reforms. As of this writing, the exit of Mubarak has not produced significant changes in the powerful economic or political organizations controlling Egypt.

${ }^{39}$ We draw on Alston, Mueller, and Nonnenmacher (forthcoming, esp. chap. 2).

${ }^{40}$ The size of the shadow of the court varies from country to country. For example, in Argentina, from 1946 to 2010, every administration but one (de la Rúa) has either impeached Supreme Court justices, forced resignations, or added justices (Alston and Gallo 2010). This has led to little if no constraints on the executive and legislative branches.
} 
individuals in political and economic activities. The perceived rewards and the actions undertaken produce economic and political outcomes, some of which may be consistent with the underlying beliefs of cause and effect as expected by those in power and others inconsistent with the beliefs of the designers of the formal institutions. Deep-seated behavioral and internalized (core) beliefs (as defined by Greif 2006) may often be the cause for why the outcomes deviate from the belief of policy makers. In short, the set of beliefs held by those in power about how a new institutional change will affect expected outcomes deviates from the actual outcome because the actors in society hold onto their set of behavioral beliefs, which differs from those in power who can change the rules.

The laws that countries pass will frequently entail political or economic side payments. When the side payments are transparent, we call the process lobbying or "pork." When the process is not transparent, we label the process as "corrupt.” Whether it is pork or bribes, many policy makers condemn these practices, but, as North, Wallis, and Weingast (2009) point out, they are the glue that prevents the entire system from unraveling into violence in less mature societies. For advanced societies, the pork may enable welfare-enhancing measures, and eliminating pork may make policy change impossible (Alston and Mueller 2006) or dysfunctional (Pereira and Mejía Acosta 2010).

\section{Economic and Political Outcomes}

Institutions generate incentives for economic and political activity that in turn produce economic and political outcomes. Again, we recognize that it is not simply formal institutions that determine the full set of incentives; norms also matter, as well as the differing relative prices or costs of taking certain actions - which in turn depend on institutions - and the perception of actors of the outcomes from choices. It matters for those in power if the outcomes are consistent with their beliefs because they enact institutions to change incentives, which in turn will produce outcomes that they perceived as beneficial for their goals. Political outcomes include both narrow outcomes (e.g., politicians want to get reelected) and broad outcomes (e.g., the degree of personal freedoms in a society). Economic outcomes, as well, are narrow (e.g., Did import protection increase the profits of a particular industry?) or broad (e.g., How did policies impact unemployment levels, economic growth per capita, or income inequality?). The economic and political outcomes can have two effects. If they are sufficiently different from expectations or 
repeatedly different from the expectations, they can affect the beliefs of those in power. ${ }^{41}$ In addition to affecting beliefs, the political and economic returns can change the relative power of the economic and political organizations in the dominant network. It is the change in beliefs or the change in power that generates the dynamics in our framework, producing either incremental institutional changes or more discrete large institutional changes when a window of opportunity opens along with the necessary leadership.

\section{Dynamics}

Now that we have the elements, we can discuss in broad terms the dynamics of the framework that we summarize in Figure 5. At time $t$, a society is at the left side of the figure in "autopilot" mode. This is the situation in societies in most periods. There is a set of core beliefs held by the dominant network as well as other organizations and citizens. The core beliefs shape laws and their enforcement, and we see only incremental changes because the economic and political outcomes match the expectations of the dominant network. In this state of the world, there is no role for leadership as we defined it. The world that the players face is never static, so they always take some actions to change some institutions on the margin, though others they leave as fixed.

(Figure 5 about here)

Most institutions remain fixed because the incentives that the institutions generate lead to outcomes that produce a sufficient rental stream to the organizations such that they see no reason to "rock the boat." 42 For other institutions, the dominant network tinkers on the margin. They make decisions, for example, pass laws, issue decrees, and render judicial decisions, inter alia. All these institutional modifications change incentives on the margin but do not fundamentally affect beliefs. We are in a world in which Greif (2006) argues that the institutions are consistent with the beliefs of economic and political organizations.

Beliefs about the impact that the institutional changes will have on incentives and in turn outcomes determine the institutions that are put in place, though the institutions also produce

\footnotetext{
${ }^{41}$ This is consistent with Eggertsson's (2005) argument that experiences affect social/policy models.

${ }^{42}$ Eggertsson (2005) argues that for centuries, Iceland held onto "imperfect institutions" because they benefited the agricultural elite. He argues that they held a misguided partial equilibrium social model. The landed elite feared that fostering fishing would drive agricultural wages up. They neglected to see that "a rising tide raises all boats," that is, that reaping the benefits from fisheries would foster economic growth sufficiently to increase the rent for landowners as well.
} 
some unintended consequences, sometimes small and sometimes large. ${ }^{43}$ To the extent that the overall outcomes produce adequate rents to the players in the configuration of power, we will not see "big” institutional changes, and societies may cruise along in this "autopilot” mode for decades. ${ }^{44}$ Societies function and operate under a belief system of "this is the way our world works.” The system is meeting the expectations of those in power as well as citizens; it is like a tide that washes over society. The belief system is predictable and is sustained by the social fabric of society, that is, familial, religious, social, and cultural relationships. In such a world, outcomes are consistent with expectations, so there is no organization sufficiently powerful (or with the incentive) to push for big changes.

But, at some historical moment, the cumulative effect of small changes reaches a tipping point, or there is an exogenous shock, either internal or external to a country, that shocks the system. This is shown as the shaded area moving to the right in Figure 5. The lines from each element in the "autopilot" part of the figure indicate whether that element (i.e., beliefs, dominant network, institutions, and so on) stays the same-horizontal line-or changes over time-slopes up or down. At this level of generality, we are not interested if the change was positive or negative, but simply whether something "big” has changed or not.

When a shock takes place, the only thing that changes in a first moment are the outcomes, which now no longer match expectations; see (1) in Figure 5. If this effect is large enough, it may create pressure for change, leading to a window of opportunity. As shown in Figure 5, during a window of opportunity there is the potential for leadership to initiate a critical transition. If leadership does not emerge, most societies will cycle back to the ex ante shock world with changes initiated to patch up the repercussions from the shock. ${ }^{45}$ But, if the shock is sufficiently large to shake the beliefs of many in the dominant network and someone (or some organization) takes on a leadership role, “constitutional-level” changes are possible that can set a country on the path to a critical transition. The wavy lines after point (2) in the figure indicate that the old beliefs have been lost and have not yet been substituted by new beliefs.

\footnotetext{
${ }^{43}$ Unintended outcomes result from a myriad of forces: formal institutions alone do not feed directly into outcomes; norms matter as well as the relative prices of choices faced by organizations (see Wallis 2011).

${ }^{44}$ This is analogous to how most of us live our lives. Most of us operate according to certain routines, and it takes something out of the ordinary, for example, a heart attack, to cause us to fundamentally change our way of life, though again we tinker on the margin.

${ }^{45}$ The fallout from the Arab Spring could be considered a potential window of opportunity, but no leader took charge, most likely because it was not in the interest of the dominant network whose belief did not change.
} 
The way these changes take place depends on the country and the situation, and there are infinite possibilities. As drawn in Figure 5, at point (3) leadership steps in to catalyze new beliefs of those in the dominant network, or some organizations with differing beliefs gain or lose power within the dominant network. Change does not happen simultaneously. It takes time for leadership to coordinate organizations within the network to “make a leap of faith,” and sometimes, if the shock is sufficient, the rents to the dominant network have fallen sufficiently that they have little to lose. ${ }^{46}$

In the period leading to constitutional-level changes, leadership can emerge from either within or outside the current dominant network of power. In the United States during the building of a nation with the Constitution from 1783 to 1789, Washington, Jay, Hamilton, and Madison formed a quartet of leadership (Ellis 2015). All four were by then part of the dominant network, but in a minority at the beginning. For Brazil, the leadership of Cardoso in 1993 took place while he was in the dominant network. But, as discussed below, Perón in Argentina emerged outside the dominant network. To solidify a "constitutional moment" will take years of institutional deepening where the new beliefs shape new laws that have the expected outcome that in turn feed back to organizations and citizens within and outside the dominant network. ${ }^{47}$

Leadership over time is instrumental for institutional deepening because the dominant network needs to be coordinated and rents need to flow to its members under the new belief system. In rare cases, the new beliefs simply emerge as a result of the shock, but in others, leaders can purposefully influence them. ${ }^{48}$ Not everyone changes their set of beliefs simultaneously, and some organizations in power may never change their beliefs. But if leaders can exercise cognitive and coordinative roles, a big institutional change affecting the trajectory of a country is possible. Schofield (2006) argues that Madison and Hamilton played this role in the ratification of the US Constitution in writing the majority of the Federalist Papers, which

\footnotetext{
${ }^{46}$ This was the case for Brazil during the hyperinflationary period just prior to the Plano Real. Tipping points seem most likely in the case of mass movements, for example, the demise of the Soviet Union, as successfully negotiated transitions to an extremely different dominant network are not common. We do not discuss this possibility, but it is compatible with our framework. On tipping points, see Kuran (1995). ${ }^{47}$ For Brazil, in 2003, Lula being from the opposition party sustained the transition to the new set of beliefs set in motion by Cardoso. Bidner and François (2013) stress that changes in beliefs require a change in leadership to affirm that governments are now different.

${ }^{48}$ In some situations, the shock may be sufficiently large that no matter who is in power, the actions taken will be similar. As an example, after 9/11, every conceivable president in the United States would have vowed to "hunt down" Bin Laden.
} 
swayed voters in their belief for a larger role for the federal government at the expense of the power of states. Ellis argues that Washington and Jay were also critical in the convention and ratification process. Washington brought moral authority with his endorsement, and Jay brought legitimacy because of his role in negotiating the Treaty of Paris as well as being head of the confederacy. The critical transition happens ultimately because beliefs about the way the world works have changed. This takes time and continued reaffirmation of the nascent beliefs.

The change in beliefs leads to new formal institutions, that is, both the constitutionallevel institutions and the laws/enforcement (points 4 and 5 in Figure 5). These changes in turn affect the incentives faced by individuals and organizations, affecting in turn their choices. This leads to a new trajectory toward new outcomes (initiating at point 6 in Figure 5). If outcomes now once again match expectations, this society reaches a new autopilot, on the right-hand side of the figure. For a fortunate few societies, this leads to a critical transition to a more open economic and political society. However, the outcomes in the new autopilot might be better or worse than before. Yet, they are stable in the sense that they accord with what is expected. The outcomes will naturally vary over time as they are affected by small internal and external shocks, leading to incremental changes in beliefs and organizations in power. Occasionally, large shocks or endogenous tipping points lead to new windows of opportunity, and the process may repeat, though within a different context and with different details. Note, however, that there is no reason to expect that with each new cycle the country will move ever closer to a critical transition to being more developed. On the contrary, historical experiences suggest that such trajectories are rare, and countries are more likely to shift from one underperforming state to another or to cycle forward and back without much overall long-term improvement.

The key element in the dynamic is the change in beliefs. When beliefs become uncertain, some leaders can sway which beliefs get acted on in terms of the institutions that get established. This can come about through the "art of policy making." If the new institutions produce incentives that in turn generate outcomes that are viewed as "good” or consistent with the subjective view of the way the world works, as expounded by the organizations that implemented the institutional change, then beliefs about the causal role of institutions on incentives and on outcomes deepen. For example, Rakove, Rutten, and Weingast (2004) argue that prior to the Revolutionary War between Britain and her North American colonies, only a minority of those in power in the New England colonies "believed” that Britain would take away 
the liberties of the colonists. Actions taken by the British, including the quartering of troops in New England and the disbandment of the Massachusetts legislature, gave credence to the beliefs of the New Englanders, and over time this belief that "the British will take away our freedoms" propelled the colonists to take up arms against the British.

The beliefs in the benefits from change do not happen in a vacuum: those in the dominant network (and at times, citizens at large) view the expected impact of new institutions (and their resulting incentive structure) based partially on institutions around the globe, for example, an independent judiciary, or secure property rights. In addition, many in the dominant network may have acquired part of their education in wealthy countries, which shaped their beliefs and their perceived benefits of importing institutions, though with modifications to suit their needs. ${ }^{49}$ This is true for many in the dominant network in South America as well as in Asia today. Knowledge of institutions from the outside world also allows leaders more conviction "to stay the course" when there are up-front costs for downstream benefits from institutional change.

During a window of opportunity, it is the competing and incompatible beliefs among organizations within the dominant network, either the new organizations or old organizations with new beliefs, that bring about the potential for new institutions that change incentives and (at times beliefs) and move a society toward a critical transition. ${ }^{50}$ In such a situation, competing powerful organizations are constrained by the beliefs of each other and their relative power. A new set of institutions emerges through leadership (which could be a consensual group of organizations) in the Riker sense of coordinative activity that enables a new belief system to take hold among a winning network of organizations.

Leadership entails orchestrating powerful groups to react to the perception of a problem and that the perceived solution to the problem is shaped by the beliefs of leaders about the likely consequences of the new incentives emerging from the new institutions. In this sense, our actors

\footnotetext{
${ }^{49}$ The recurrent problem with transplants, however, is the incongruence between institutions and beliefs.

${ }^{50}$ Competition over beliefs brings about only the "potential" for moving to a more open society. The result depends on the beliefs of those who win the competition for power. Our concept of "windows of opportunity" is similar to that of Acemoglu et al. (2008), who argue that economic growth does not necessarily lead to democracy and whether it does they label a critical juncture. They reach this conclusion after an econometric exercise that convincingly demonstrates that country-specific effects make the difference. As discussed earlier, the difference between a critical juncture and a window of opportunity is that in a window of opportunity, the actors realize the potential and are forward looking as well as solving current problems.
} 
are both forward and backward looking. ${ }^{51}$ Here is where today's threshold countries can learn from the experiences of countries that have already made the critical transition. Of course, those in power can't perfectly foresee the outcomes of their actions, but they can make an educated prediction. ${ }^{52}$ In addition, today's leaders recognize that a "big bang” (e.g., the dissolution of the former Soviet Union) is not sufficient for development, though it may be necessary. As we stressed earlier, the "big bang" must be sustained with complementary changes in beliefs along with further downstream institutional deepening. All that leaders can foresee is that putting in place certain incentives - through institutional change-will have some likely foreseen outcomes and some unforeseen outcomes. Leaders must be responsive to unanticipated downstream consequences. North (1990) referred to this process as "adaptive efficiency."53 Of course, knowing what to do differs from having the incentive to change. In many countries, it is in the economic and political interests of the dominant network in power not to initiate changes to a critical transition. Not everyone wins during a critical transition. Today, it is less likely a cognitive issue than 150 years ago when the pioneer countries began their critical transitions.

A critical transition is problematic because the future has uncertainty. Some groups will lose. Moreover, generally opening up the economy entails considerable up-front costs; for example, stabilization policies typically have short-run costs with long-run benefits. This means giving up political and economic rents in the short run for some unknowable but perceived ex ante increase in rents in the future for society as a whole, though with unforeseen distributional consequences. Part of the solution to development is recognition that a winning political network of organizations foresees more advantages from promoting openness than the extant status quo. This is why windows of opportunity are so important. In Brazil in 1993, a stabilization plan quelling hyperinflation (the Plano Real) succeeded in part because after a series of hyperinflationary periods and failed stabilization plans, those in the dominant network in Brazil

\footnotetext{
${ }^{51}$ This differs from the North, Wallis, and Weingast (2009) view, where the actors are primarily solving extant problems and not as forward looking as today's leaders/organizations can be. But, we agree with North, Wallis, and Weingast that actors are solving current problems; the difference is that today's leaders can be more forward looking because of the experiences of other countries.

${ }^{52}$ Of course, this does not dismiss the role for unintended consequences of which history redounds.

${ }^{53}$ In this sense, our actors are forward looking, similar to the Acemoglu, Johnson, and Robinson (2005) versions of England and Spain responding differentially to oceanic trade. In other versions of Acemoglu and Robinson (2006, 2012), the elites are forced by citizens to give up rents. We believe that today, citizens have a greater role to play in the developmental process in proportion to the extent that the rule of law pertains to a greater percentage of citizens. As of this writing, there are large, peaceful street protests in Brazil hoping to bring down the Dilma Rousseff government.
} 
believed that taming inflation was the number one priority for Brazil in the early 1990s. Enacting political and economic institutional changes requires some risks to those in power, and this is where the leadership of Cardoso and his economic team mattered. Opportunities present themselves, but not all potential leaders take advantage of the opportunity because they lack the perception to see the opportunity; they perceive an opportunity but lack the knowledge of what to do; or they lack adaptability, the art of policy making in the dynamic sense expounded by Riker (1984, 1996).

Recognizing a role for leadership is a departure from the standard economic and political rational-choice models consisting of "representative agents." We recognize that this leads to a certain degree of arbitrariness, which is why we are proponents of case studies that entail thick description in the same way that courtrooms need to rely on circumstantial evidence when there is not a "smoking gun." ${ }^{54}$ Windows of opportunity allow leaders to affect institutional changes that can lead to incentives that produce less or more political or economic openness than the previous order. Windows of opportunity are not unidirectional in proceeding from less to more openness; the reverse is equally likely.

At times, leaders enact "big” institutional changes that lead to incentives producing outcomes consistent with expectations and also lead to a critical transition because a greater number of organizations in the dominant network see a higher expected gain from the new institutions. This requires a complementary change in the way the world now works. For example, in the political arena, if the electorate rewards politicians for increasing political and economic openness within a framework of rule of law, there is a tendency for the dynamic to become virtuous with institutional deepening; that is, successive smaller institutional changes buttress the initial "big" institutional change. Belief deepening must accompany institutional deepening (Greif 2006; Bidner and François 2013). Institutional deepening is necessary for countries to reach a critical transition - the big institutional change is neither sufficient nor sustainable without a belief deepening. Moreover, many seemingly "big” institutional changes are never sustained because they are not buttressed with other supporting smaller institutional changes and are not accompanied by changing beliefs among the dominant network in society. Whether institutional changes are really "big” can be judged only ex post.

\footnotetext{
${ }^{54}$ On the role of circumstantial evidence in history, see Fogel (1982). See also Collier (2011) for the distinctions between "smoking gun" and other types of explanations in political science.
} 
In the empirical chapters of Alston et al. (forthcoming 2016), we demonstrated that in Brazil the Plano Real led to taming inflation, but it was the subsequent smaller but important institutional changes from 1994 through the two terms of Lula and early part of Rousseff's term that produced a very different Brazil from the one in 1994, or 1985, the end of the military regime (Alston et al. forthcoming 2016). Politicians found it in their interest over time to provide public goods to secure votes, and citizens in a competitive political system tolerated less corruption in society. Increasingly, the rule of law evolved and applies to political rulers in the sense that they are not above the law; impeachments are a sign that leaders are not above the law. ${ }^{55}$ In the economic system, regulation and loans can be used preferentially or in patron-client fashion, but politicians came to realize that such treatment no longer delivers the same political support nor generates economic growth for consumers. In Brazil, the movement to a critical transition produced a more impersonal and open society. ${ }^{56}$

From the lenses of history, we know that reaching a critical transition is not an easy task and is not inevitable. Indeed, those countries that have made the critical transition are the exception rather than the rule (North, Wallis, and Weingast 2009; Acemoglu and Robinson 2012). The answer appears to be so highly country-specific that generalizations can take the form of only very broad frameworks such as the one we present here based on the Brazilian experience. Whether the inductive framework developed here will be helpful in understanding development in general will come from its successful application to other case-study countries. In the next section, we present an illustrative overview of how our framework can be applied to Argentina, a country that in the early twentieth century was seen as on a trajectory to sustainable development.

\footnotetext{
${ }^{55}$ In the early years of democratization, Collor, the first elected president in Brazil, was impeached for corruption, and yet the transition of the vice president to the presidency was peaceful, and the process evolved according to the formal institutions put in place in the constitution. There was never a hint that the military would take over the government. Currently, President Rousseff is being considered for impeachment. The news of a possible impeachment bolstered both the exchange rate and stock market, suggesting a peaceful transition to a more market-friendly president.

${ }^{56}$ The prosecution on corruption charges associated with the Petrobrás scandal of high-level corporate executives as well as the past and current presidents in Brazil is testimony that they are moving to a situation where no one is above the law.
} 


\section{Argentina: An Illustrative Use of the Framework}

From 1890 until 1950, Argentina ranked between 7th and 30th in its GDP per capita (Alston and Gallo 2010: 180). ${ }^{57}$ In 2015, it ranked 52nd, clearly a fall from grace (IMF, World Economic Outlook Database ${ }^{58}$ ). What happened? At the dawn of the twentieth century, Argentina had a relatively good endowment of natural resources coupled with little or no ethnic tensions or indigenous issues. The country had fertile land in the Pampas especially suited for wheat and cattle. It was an attractive destination for immigrants. Using our framework, we will discuss the development of Argentina in three periods: (1) 1912-1930, (2) 1930-1946, and (3) 1946-2016. ${ }^{59}$ We will devote most of our attention to the period 1930-1946, which was the crucial period for understanding the condition of Argentina today.

\section{The Camelot Years: 1912-1930}

From the late nineteenth century until 1914, the dominant network consisted of the rural agricultural landowners and the educated elites of Buenos Aires. The dominant network stayed in power through their control of the electoral process, which conforms to being on an autopilot dynamic. The lack of political voice sparked three failed armed revolts in 1890, 1893, and 1905, consisting of some factions of the military and the rising class of laborers in Buenos Aires and the countryside. The rising discontent also led to the formation of political parties to champion the voice of laborers. But, this was for naught until the election of Sáenz Peña in 1910. Sáenz Peña saw the protests and the increasing power in the streets held by the Radical Civil Union Party as a window of opportunity for change. Though part of the ruling elite, Sáenz Peña believed that to be a modern nation required open elections. He made his intentions known of moving to open elections in his speech before Congress in 1910. By 1912, his leadership had

\footnotetext{
${ }^{57}$ We stress that this section is illustrative and we can certainly not capture the nuances of Argentine development over the period discussed. Our hope is that the illustration will motivate scholars of Argentina to more fully develop a case study using the framework that in turn will inductively help make our framework more generalizable. This material draws extensively on Gallo and Alston (2008), and Alston and Gallo (2010). We single out Alan Dye, along with an anonymous reviewer, for giving us detailed comments on this section.

${ }^{58}$ http://www.imf.org/external/pubs/ft/weo/2010/02/weodata/download.aspx.

${ }^{59}$ We are taking some liberties in classifying 1946-2016 as one period. We do so for two reasons: (1) the period opens with a window of opportunity seized by Juan Perón and ends in December with Mauricio Macri seizing a window of opportunity by his abrupt switch to fiscal orthodoxy following almost immediately after assuming the presidency in December 2015; and (2) we view Argentina's oscillations between populism and conservative military regimes until the military budget was stripped in 1983 as a form of autopilot. Except for Menem's tenure, populism has reigned except for the newly elected Macri.
} 
convinced a majority to support his law calling for a secret ballot. The law giving universal suffrage to males, enforcing compulsory voting, and, most importantly, instituting the secret ballot passed in 1912 and bears his name, the Sáenz Peña Law. The Sáenz Peña Law called for stricter monitoring for electoral fraud and also promoted naturalization of immigrants and the granting of citizenship to the children of immigrants. The Sáenz Peña Law changed the trajectory of Argentina because it initiated a change in the beliefs toward a democracy that believed in checks and balances.

Prior to the secret ballot, the Conservatives, dominated by the agricultural producers in the Pampas, controlled the legislative and executive branches and appointed relatively conservative Supreme Court justices. Hipólito Yrigoyen, a leader in the Radical Party, won the first presidential election in 1916 following the introduction of the secret ballot. The Radical Party controlled the presidency and the House of Deputies, with the Conservatives having a majority in the Senate. Divided governance held throughout the 1920s. Alston and Gallo (2010) refer to this as the Camelot period for Argentina, one in which the players (for the most part) respected the nascent system of checks and balances. ${ }^{60}$

Argentina in many ways considered itself “different” from the rest of South America. The increased openness in the political arena represented a belief in democracy and a prominent role for checks and balances. The belief in checks and balances was a budding belief from below and fragile within the dominant network, though firmly held by the Radical Party. During this period, the dominant network was relatively large with several constituencies having a voice-urban and rural workers who tended to vote for the Radical Party, and the urban and rural elite who tended to vote for the Conservative Party. One measure of transparency was the dramatic increase in the number of roll call votes following 1916 and continuing through the 1920s. In addition, the number of voters went up dramatically, and even more importantly, the Supreme Court exercised a degree of independence overturning laws favored by the legislature and the president. The losers respected the judgment of the court. Much of the legislation during the period dealt with issues of concern to the working class, for example, rent control for tenants and rural workers. Overall, the period brought high growth with GDP/P averaging 4.2 percent over the period. Both the elite and the workers benefitted during this robust period of growth. But, as we noted earlier,

\footnotetext{
${ }^{60}$ We note that Yrigoyen resorted to executive interventions relatively frequently during his two terms in office in order to circumvent legislation proposed by the Conservatives. We thank Sebastian Saeigh for this insight.
} 
"development" is about more than economic growth. Its hallmarks are transparency, rule of law, and economic and political competition, inter alia. For these reasons, this period in Argentine history represented true “development.” Unfortunately, this fourteen-year run on the path to a “critical transition” came to a hiatus with a military coup in 1930 that ousted the Radical president Yrigoyen.

\section{Electoral Fraud and the Rise of Perón: 1930-1946}

The Great Depression shocked the economic system. The Conservatives, particularly those aligned with agriculture, felt that the government must "do something." Precisely what action to take was not clear. Being a major exporter of wheat and beef, Argentina was hit hard by the plunge in commodity prices; from December 1929 to December 1930, wheat prices (in Liverpool) fell from $\$ 1.41 /$ bushel to $\$ 0.74$, and Argentine beef fell from $\$ 5.92 / 100 \mathrm{lb}$. to \$3.67/100 lb. (US Department of Agriculture 1936: 21; 216). Both parties believed that the crisis warranted action. Legislative bills languished at the executive level, where neglect was the norm. The aging President Yrigoyen either was incapable of sensing the depth of the recession or simply did not know what to do. Either way, the Great Depression coupled with the passive Yrigoyen prompted the military to oust Yrigoyen at the behest of the Conservatives and with the countenance of the Radical Party. The Radical Party did not mount a protest because many in their party were also frustrated with Yrigoyen in not grasping the seriousness of the downturn. Though the coup was an affront to the electoral process and the constitution (as well as the first in Argentine history), most parties anticipated a quick transition back to legitimate elections. This was not to be.

The military installed the Conservatives in power (de facto) and looked for legitimacy. During this early period, the military and the Conservatives were closely aligned. The Supreme Court labeled the coup a "triumphant revolution" (Alston and Gallo 2010: 182). Only one Supreme Court justice resigned in protest. The military planned to transition back to elections and the path to solidifying the critical transition. The Conservatives thought that citizens would recognize that the Conservative elite should run the government during an international economic crisis. The military and Conservatives misread the public. The first free election was in the province of Buenos Aires in April 1931. To the surprise of the Conservatives, the Radicals won the election, and the military annulled the results. The military called for a national election 
in 1932 but did not allow any candidates from the Radical Party who had been in office during Yrigoyen's final term. The Radicals protested by refusing to recognize and participate in the election. As a result, the Conservatives returned to power in 1932 with the military in the wings if needed. The dominant network consisted of agricultural producers and others associated with exports; the Conservative Party; and the military. The combined actions of annulling an election and preventing the Radicals from having candidates marked the beginning of the departure away from sustainable political and economic development.

The prevailing belief held by the Conservatives and their military allies - the de facto dominant network - was that the emergency of the Great Depression necessitated rule by the Conservatives. Ironically, the Conservatives received high marks for their macroeconomic policy during the 1930s (Della Paolera and Taylor 1998, 1999, 2001). But, to stay in power, the Conservatives resorted to electoral fraud (known by its advocates as "Patriotic Fraud") throughout the 1930s. ${ }^{61}$ The economic outcomes desired by the dominant network met their expectations, but they trampled on the political rights of the Radicals and their allies. The Radicals protested but to no avail. The Supreme Court stood on the sidelines on the grounds that the fraud was a political, not a constitutional, issue. The persistent fraud throughout the 1930s led to an erosion among the electorate in the belief that a system of checks and balances could ever be legitimately implemented in Argentina:

The Conservative regimes of the 1930s, in spite of their flirtations with fascist reformism, brought to a halt the modest momentum for political and social reform started by the Radical governments. Their failure to buttress the relative healthy economic structure with social and political arrangements allowing for growing security and political participation for rural and urban masses contributed to the creation of revolutionary possibilities. In short, the Conservatives appeared to have won the battle by fraud but lost the war by abandoning the rule of law. (Díaz Alejandro 1970: 107-8)

In 1940, President Ortiz promised to return to nonfraudulent elections in 1942. Ortiz signaled an intention to return to the path that had been interrupted by the Great Depression and the nonlegitimate rule of the Conservatives. This marked a potential window of opportunity created by the leadership of Ortiz. Whether transparent elections were possible under the rule of

\footnotetext{
${ }^{61}$ For an in-depth account of fraud in the 1930s, see Alston and Gallo (2010) and sources cited therein. A slight majority of the total reports of fraud come from three provinces in the Pampas: Buenos Aires, Entre Rios, and Santa Fe. The Province of Cordoba (in the Pampas) never engaged in fraud and consistently elected Radicals to the House of Deputies.
} 
Conservatives is a counterfactual that we will never know because Ortiz fell ill early in his term and died on June 27, 1942, several months before the general elections. His successor, President Castillo, resorted to fraud to sustain the Conservatives in power in the elections of 1942.

Castillo's reign was short-lived. A faction of the military defected from the former dominant network of Conservatives and ousted Castillo in June 1943. Many thought (or hoped) that the new military government would return quickly to democracy. This might have happened, but a nationalistic faction within the military relatively quickly took control. Juan Perón was an important player within the nationalistic faction and held several powerful posts. He quickly demonstrated his support for labor and opposition to the Conservatives.

To the surprise of many, the military government called for free elections in 1946 with Perón as their candidate. Perón campaigned through skillful oratory as well as on his record for supporting labor. He openly showed his populist streak and contempt for the conservative court, which had countenanced the electoral fraud in the 1930s. The election was clean. Perón won the election with a majority of 52 percent (Ciria and Astiz 1978). In the absence of fraud in the 1930s, Perón may well have not won the election in 1946 (Alston and Gallo 2010). ${ }^{62}$ Perón’s support was strongest in the provinces where fraud had been the greatest. Additional support for the view that electoral fraud in the 1930s drove the support for Perón comes from the electoral results in Cordoba. Cordoba did not engage in fraud in the 1930s, and Perón did not receive a majority of votes in Cordoba in 1946.

We view the election of Perón a "shock" to the system, and a new window of opportunity under the leadership of Perón that set Argentina on a new trajectory with a different set of beliefs from those held by the dominant network of Conservatives in the 1930s. A majority of citizens had lost faith in the system of checks and balances because of the electoral fraud. Perón played to the choir by expressing his support for the "will of the people." The new dominant network under the leadership of Perón consisted of factions of the military, labor, and most of the rural provinces. In addition to being able to count on the working classes because of his policy positions, Perón exhibited leadership by coordinating the dominant network through the use of subsidies to rural provinces outside of the Pampas. The transfers to rural provinces made

\footnotetext{
${ }^{62}$ Alston and Gallo (2010) report regression results that show that if there had been no fraud in the 1930s, then Perón would not have won the election. Of course, without fraud, there may never have been a military coup, but the purpose of the exercise is to show the rise in the belief of populism promoted by Juan Perón.
} 
governors more powerful, and in return they supported Perón. Perón took advantage of the window of opportunity and, with the support of the new dominant network, initiated institutional changes consistent with a belief in populism. Perón saw the Supreme Court as an obstacle to his agenda, and impeaching most of the court was his first order of business. This would turn out to have long-run consequences.

\section{Instability Is the Rule: 1946-2016}

We treat this nearly seventy-year period as one episode, not because it remained constant but rather because the entire period has been marked by incredible policy instability that until the mid-1980s led to oscillations between populist governments siding with labor, and conservative/military governments siding with the conservative agricultural sector in the Pampas. ${ }^{63}$ Oscillations between the military and Perónists became a de facto autopilot until President Alfonsin slashed the budgets of the military in 1984. Menem recognized a window of opportunity in the mid-1990s to change the trajectory of Argentina, but he failed to exercise sufficient leadership to accomplish his goal of fiscal and monetary orthodoxy.

After being elected president, Perón acted quickly to solidify his populist agenda. ${ }^{64} \mathrm{He}$ displayed the leadership characteristics of cognition of the issues that he wished to address, an extraordinary ability to coordinate interests in his dominant network, and some moral authority based on his time in prison as well as his great oratory skills. Many of his actions most likely would have been considered unconstitutional by the conservative Supreme Court that Perón inherited. Perón set his sights early on impeaching all but one of the Supreme Court justices. Perón clearly expressed his contempt of the court:

In my opinion, I put the spirit of justice above the Judicial Power, as this is the principal requirement for the future of the Nation. But I understand that justice, besides from being independent has to be effective, and it cannot be effective if its ideas and concepts are not with the public sentiment. Many praise the conservative sentiment of the Justices, believing that they defend traditional beliefs. I consider that a dangerous mistake, because it can put justice in opposition with the popular feeling, and because in the long run it produces a rusted organism. Justice, in its doctrines, has to be dynamic instead of static.

\footnotetext{
${ }^{63}$ For a more detailed discussion of the subperiods, especially related to policy instability, see Spiller and Tommasi (2009). Gallo and Alston (2008) show the instability in banking, fiscal policy, foreign trade, and constitutional politics.

${ }^{64}$ By populism, Perón (and we) meant ruling by the will of the people with little respect for the minority rights of the agricultural elite in the Pampas. Perón saw as his primary constituencies the urban and rural working classes. To bring the outlying provinces into his network, he relied on transfers.
} 
Otherwise respectable popular yearnings are frustrated and the social development is delayed, producing severe damage to the working classes when these classes, which are naturally the less conservative, in the usual sense of the word, see the justice procedures closed they have no other choice than to put their faith in violence. (Diario de Sesiones del Honorable Senado de la Nacion Constitutido en tribunal, T. VI, December 5, 1946: 89; quoted in Alston and Gallo 2010: 192)

With this statement, Perón clearly aligned himself with working classes and felt the executive power should reign supreme. The Perónists in the House of Deputies went to great lengths to tie the impeachment of the court not just to their obstruction to the new Perón policies but also to their countenance of the electoral fraud of the 1930s. Perón and his allies won, and all the accused justices were impeached. With new appointments to the court by Perón, there was no opposition to the new Perónist agenda. A new belief system was in place with a new dominant network consisting of the working class (urban and rural), nationalists, and allies from the outlying provinces that Perón brought into the network through the strategic use of directed transfers. The Perónist agenda consisted of, to a large extent, taxing landowners in the agricultural Pampas and redistributing it to members of the dominant coalition. He did this by establishing a national price for cattle and wheat that the government paid and then exported at a higher price. He used the surplus to subsidize outlying provinces. To promote his agenda, he nationalized several public utilities (e.g., railroads, telephone, and water). As populist measures appeasing his major constituencies, rent controls and the thirteenth-month wage payment stand out.

Perón increased expenditures faster than revenues increased. His sources of revenues included export taxes (particularly beef and cattle), revenue from state enterprises (many nationalized utilities), and seigniorage from increasing the monetary base and monetizing debts of provincial banks. To rely on seigniorage required taking away the independence of the Central Bank. At first, outcomes matched expectations, but over time, deficits mounted to an unsustainable level such that toward the end of Perón's reign, Argentina could no longer borrow on the international market (Díaz Alejandro 1970). The taxing of the Pampas also led to less domestic and, most notably, foreign investment in the Pampas. Inflation during Perón's time in office was nearly 20 percent but increased even more rapidly in the years following Perón's first two terms. Most notable was the decline in foreign investment. 
The steadily eroding fiscal situation in Argentina slowly but surely opened a window of opportunity for Conservatives to retake control of the dominant network. A military coup in 1955, with a faction opposed to Perónists, set in motion the oscillations in policy that dominated Argentina's slide from one of the wealthiest countries in the world. The new military-led dominant network in 1955 consisted of Catholic nationalists and a liberal/conservative coalition. The new regime tried to undo some of the confiscatory and redistributive policies of Perón, especially the control of beef and cattle prices and the elimination of price controls. But, given the extant power of unions and the large number employed in the public sector, the military regime ultimately resorted to inflation to stay afloat. Of course, this was not sustainable. Policy oscillated because the military favored the Pampas. Like Perón, the military regime wrote a new constitution and forced the resignation of all five members of the Supreme Court. The military regime allowed limited elections in 1958 (the Perónist Party was formally banned).

We view the oscillations of policies and regimes as an ex post form of autopilot. We see the populists and the Conservatives as competing for control of the dominant network, but neither side having sufficient power once Perón was initially ousted from power in 1955 . With a return to limited democracy (1958-1962), policies again oscillated, continuing to hurt foreign and direct investments. The administration reinstated price controls and nationalized the oil industry. The court also increased to seven justices. The democracy proved short-lived and was followed by another coup in 1962, which too was short-lived. Argentina continued to oscillate back and forth from military to democratic regimes from Perón’s first two terms up until Perón’s return to Argentina and reelection in 1973. Each government up to de la Rúa in 1999 forced resignations, impeached justices, or added justices. As a result, the judiciary was never a constraint on the executive, and the legislature was either pliable because of its reliance on transfers from the national government or nonexistent during the military periods. Argentina eventually tied the hands of the military during the term of Alfonsín (1983-1989) and has remained populist since 1983, except for an attempt during Menem's ten-year term (1989-1999) to stabilize the economy.

Like in Brazil, the hyperinflation in Argentina in 1989 (1,200 percent/year) gave Menem a window of opportunity to fundamentally change Argentina. He tried with the convertibility plan in 1991, pegging the peso to the dollar with open convertibility. It was a bold move signaling to the world that the provincial overspending in Argentina must be reined in. 
Regrettably, Menem lacked the leadership skills to change the fiscal game in Argentina, and the convertibility plan began to unravel in 2000. The Convertibility Law was officially repealed in January 2002, and Argentina went back to its populist ways with the election of Néstor Kirchner in 2003, followed by Christina Fernandez (the wife of the deceased Kirchner). Except for a brief period in the late 1990s, foreign direct investment has remained low, frequent bouts with hyperinflation (triple-digit inflation from 1976 to 1990), and federal deficits swinging wildly. Since 2001, Argentina and its creditors have been waging legal battles over whether Argentina reneged on its contractual obligations. In 2012, a New York District Court ruled that Argentina was in default of its obligations, and in 2014 the same court ruled them in contempt of court for not meeting its judicial decision. In 2015, Argentina's credit rating was one of the worst in the world. The economic malaise besetting Argentina brought particular attention to the election for president in the fall of 2015. Christina Fernandez could not run because of term-limit restrictions. Fernandez backed an heir apparent, the governor of Buenos Aires, but he faced stiff competition from Mauricio Macri, the mayor of Buenos Aires who ran on a platform of liberalizing the economy and stamping out the corruption. Macri won the election, receiving 51.5 percent of the vote.

After assuming the presidency on December 10, 2015, Mauricio Macri moved swiftly to seize the window of opportunity left by ten years of populist overspending under Kirchner and Fernandez. He has acted on the beliefs that brought him the presidency. He passed legislation allowing the peso to float, and successfully negotiated Argentina's foreign debt. Argentina can once again issue debt based on the rising reputation of Marci’s stated friendly market policies. Whether his outcomes will match his expectations and initiate a virtuous cycle toward economic and political openness only time will tell.

\section{Concluding Remarks}

We reiterate: economic and political development is contextual. But, there are lessons for development from understanding the process, which has some general features. In Alston et al. (forthcoming 2016), we developed a framework for understanding development in Brazil over the past fifty years, and the framework presented here is inductive from the Brazilian experience. To illustrate its wider applicability, we applied the framework very generally to understand the critical transitions in Argentina from the early twentieth century to 2016. The key elements in 
our framework are beliefs and leadership, which interact synergistically and vary across countries. Because beliefs and leadership cannot be measured rigorously and classified, the use of the framework necessarily involves subjectivity and interpretation. With more case studies applying our framework, we can construct more general lessons on the dynamics among beliefs, power, leadership, institutions, policies, and outcomes that form stasis or development. 


\section{References}

Acemoglu, Daron, Simon Johnson, and James A. Robinson. 2005. "Institutions as the Fundamental Cause of Economic Growth.” In Handbook of Economic Growth, ed. Philippe Aghion and Steve Durlauf, 385-472. New York: North Holland.

Acemoglu, Daron, Simon Johnson, James A. Robinson, and Pierre Yared. 2008. "Income and Democracy.” American Economic Review 98(3): 808-42.

Acemoglu, Daron, and James A. Robinson. 2000. "Why Did the West Extend the Franchise? Democracy, Inequality, and Growth in Historical Perspective.” Quarterly Journal of Economics 115(4): 1167-99.

- 2006. Economic Origins of Dictatorship and Democracy. New York: Cambridge University Press.

. 2012. Why Nations Fail: The Origins of Power, Prosperity, and Poverty. New York: Random House.

- 2013. “Economics versus Politics: Pitfalls of Policy Advice.” Journal of Economic Perspectives 27(2): 173-92.

Ahlquist, John, and Margaret Levi. 2011. "Leadership: What It Means, What It Does, and What We Want to Know about It.” Annual Review of Political Science 14: 1-24.

Aliber, Robert Z., and Charles P. Kindleberger. 2015. Manias, Panics, and Crashes: A History of Financial Crises. 7th ed. New York: Palgrave Macmillan.

Alston, Lee J., and Andrés A. Gallo. 2010. "Electoral Fraud, the Rise of Peron and Demise of Checks and Balances in Argentina.” Explorations in Economic History 47(2): 179-97.

Alston, Lee J., Marcus André Melo, Bernardo Mueller, and Carlos Pereira. Forthcoming 2016. Brazil in Transition: Beliefs, Leadership, and Institutional Change. Princeton, NJ: Princeton University Press.

Alston, Lee J., and Bernardo Mueller. 2006. "Pork for Policy: Executive and Legislative Exchange in Brazil.” Journal of Law, Economics, and Organization 22(1): 87-114.

Alston, Lee J., Bernardo Mueller, and Tomas Nonnenmacher. Forthcoming. Institutional and Organizational Analysis: Concepts and Applications. New York: Cambridge University Press.

Bates, Robert H., Rui J. P de Figueiredo Jr., and Barry R. Weingast. 1998. "The Politics of Interpretation: Rationality, Culture, and Transition.” Politics and Society 26: 603-42.

Bidner, Chris, and Patrick François. 2013. “The Emergence of Political Accountability.” Quarterly Journal of Economics 128(3): 1397-448.

Ciria, Albert O., and Carlos Alberto Astiz. 1978. Parties and Power in Modern Argentina, 19301946. Albany: State University of New York Press.

Collier, David. 2011. “Understanding Process Tracing.” PS: Political Science and Politics 44(4): 823-30.

Della Paolera, Gerardo, and Alan M. Taylor. 1998. "Finance and Development in an Emerging Market: Argentina in the Interwar Period.” In Latin America and the World Economy since 1800, ed. John H. Coatsworth and Alan M. Taylor, 139-70. Series on Latin American Studies. Cambridge: David Rockefeller Center for Latin American Studies; distributed by Harvard University Press. . 1999. "Economic Recovery from the Argentine Great Depression: Institutions, Expectations, and the Change of Macroeconomic Regime.” Journal of Economic History 59(3): 567-99. 
. 2001. "Bailing Out: Internal versus External Convertibility.” In Straining at the Anchor: The Argentine Currency Board and the Search for Macro-economic Stability, 18801935, ed. Gerardo della Paolera and Alan M. Taylor, 165-87. National Bureau of Economic Research Series on Long-Term Factors in Economic Development. Chicago: University of Chicago Press.

Díaz Alejandro, C. F. 1970. Essays on the Economic History of the Argentine Republic. New Haven, CT: Yale University Press.

Eggertsson, Thráinn. 2005. Imperfect Institutions: Possibilities and Limits of Reform. Ann Arbor: University of Michigan Press.

Ellis, Joseph J. 2015. The Quartet: Orchestrating the Second American Revolution, 1783-1789. New York: Alfred A. Knopf.

Fiorina, Morris, and Kenneth Shepsle. 1989. "Formal Theories of Leadership: Agents, AgendaSetters, and Entrepreneurs.” In Leadership and Politics, ed. Bryan D. Jones, 17-40. Lawrence: University Press of Kansas.

Fogel, Robert W. 1982. “Circumstantial Evidence in 'Scientific' and Traditional History.” In Philosophy of History and Contemporary Historiography, ed. D. Carr, W. Dray, and T. Geraets, 61-112. Ottawa, Canada: University of Ottawa Press.

Frohlich, N., J. Oppenheimer, and O. C. Young. 1971. Political Leadership and Collective Goods. Princeton, NJ: Princeton University Press.

Gallo, Andrés A., and Lee J. Alston. 2008. “Argentina’s Abandonment of the Rule of Law and Its Aftermath.” Journal of Law and Policy 26: 153-82.

Greif, Avner. 2006. Institutions and the Path to the Modern Economy: Lessons from Medieval Trade. New York: Cambridge University Press.

_. 2008. "The Normative Foundations of Institutions and Institutional Change." Unpublished manuscript.

_. 2012. "Institutions and Leadership.” Book manuscript in progress.

Greif, Avner, and Jared Ruben. 2014. “The Institutional Basis of Political Legitimacy: The Reformation and the Origin of the Modern Economy in England.” Working Paper, Chapman University.

Hall, Peter. 1989. The Political Power of Economic Ideas: Keynesianism across Nations. Princeton, NJ: Princeton University Press.

Harberger, Arnold C. 1998. “A Vision of the Growth Process.” American Economic Review 88(1): 1-32.

Higgs, Robert. 1987. Crisis and Leviathan: Critical Episodes in the Growth of American Government. New York: Cambridge University Press.

Jones, Benjamin F., and Benjamin A. Olken. 2005. "Do Leaders Matter? National Leadership and Growth since World War II.” Quarterly Journal of Economics 120(3): 835-64.

Knight, Frank H. 1921. Risk, Uncertainty, and Profit. Boston: Hart, Schaffner, and Marx; Houghton Mifflin.

Kuran, Timur. 1995. Private Truths, Public Lies: The Social Consequences of Preference Falsification. Cambridge, MA: Harvard University Press.

McCloskey, Deirdre. 2006. The Bourgeois Virtues: Ethics for an Age of Commerce. Chicago: University of Chicago Press. . 2010. Bourgeois Dignity: Why Economics Can't Explain the Modern World. Chicago: University of Chicago Press. 
Mokyr, Joel. 2009. The Enlightened Economy: An Economic History of Britain, 1700-1850. New Haven, CT: Yale University Press.

Neal, Larry. 1993. The Rise of Financial Capitalism: International Capital Markets in the Age of Reason. New York: Cambridge University Press.

Neustadt, R. 1990. Presidential Power and the Modern Presidents: The Politics of Leadership from Roosevelt to Reagan. New York: Free Press.

North, Douglass C. 1981. Structure and Change in Economic History. New York: Norton. . 1990. Institutions, Institutional Change and Economic Performance. New York: Cambridge University Press.

- 2005. Understanding the Process of Economic Change. Princeton, NJ: Princeton University Press.

North, Douglass C., John Joseph Wallis, Steven B. Webb, and Barry R. Weingast. 2012. In the Shadow of Violence: Politics, Economics and the Problems of Development. New York: Cambridge University Press.

North, Douglass C., John Joseph Wallis, and Barry R. Weingast. 2009. Violence and Social Orders: A Conceptual Framework for Interpreting Recorded Human History. New York: Cambridge University Press.

Peele, Gillian. 2005. “Leadership and Politics: A Case for a Closer Relationship?” Leadership 1(2): 187-204.

Pereira, Carlos, and Andrés Mejía Acosta. 2010. "Policymaking in Multiparty Presidential Regimes: A Comparison between Brazil and Ecuador.” Governance 23(4): 641-66.

Rakove, Jack, Andrew R. Rutten, and Barry R. Weingast. 2004. "Ideas, Interests, and Credible Commitments in the American Revolution.” Working Paper, Hoover Institution, Stanford University, August.

Riker, William H. 1983. "Political Theory and the Art of Heresthetics." In Political Science: The State of the Discipline, ed. Ada W. Finifter. Washington, DC: American Political Science Association.

— 1984. "The Heresthetics of Constitution-Making: The Presidency in 1787, with Comments on Determinism and Rational Choice.” American Political Science Review 78(1): 1-16.

- 1996. The Strategy of Rhetoric: Campaigning for the American Constitution. New Haven, CT: Yale University Press.

Schofield, Norman. 2006. Architects of Political Change: Constitutional Quandaries and Social Choice Theory. New York: Cambridge University Press.

Shepsle, Kenneth A. 2016. "Rule Breaking and Political Imagination.” Book manuscript in progress.

Spiller, Pablo T., and Mariano Tommasi. 2009. The Institutional Foundations of Public Policy in Argentina: A Transaction Cost Approach. New York: Cambridge University Press.

US Department of Agriculture. 1936. Agricultural Statistics 1936. Washington, DC: US Department of Agriculture.

Wagner, R. 1966. "Pressure Groups and Political Entrepreneurs.” Public Choice 1(1): 161-70.

Wallis, John Joseph. 2011. "Institutions, Organizations, Impersonality, and Interests: The Dynamics of Institutions.” Journal of Economic Behavior and Organization 79(1-2): 4864. 2016. "Leviathan Denied: Rules, Governments, and Social Dynamics.” Book manuscript in progress. 

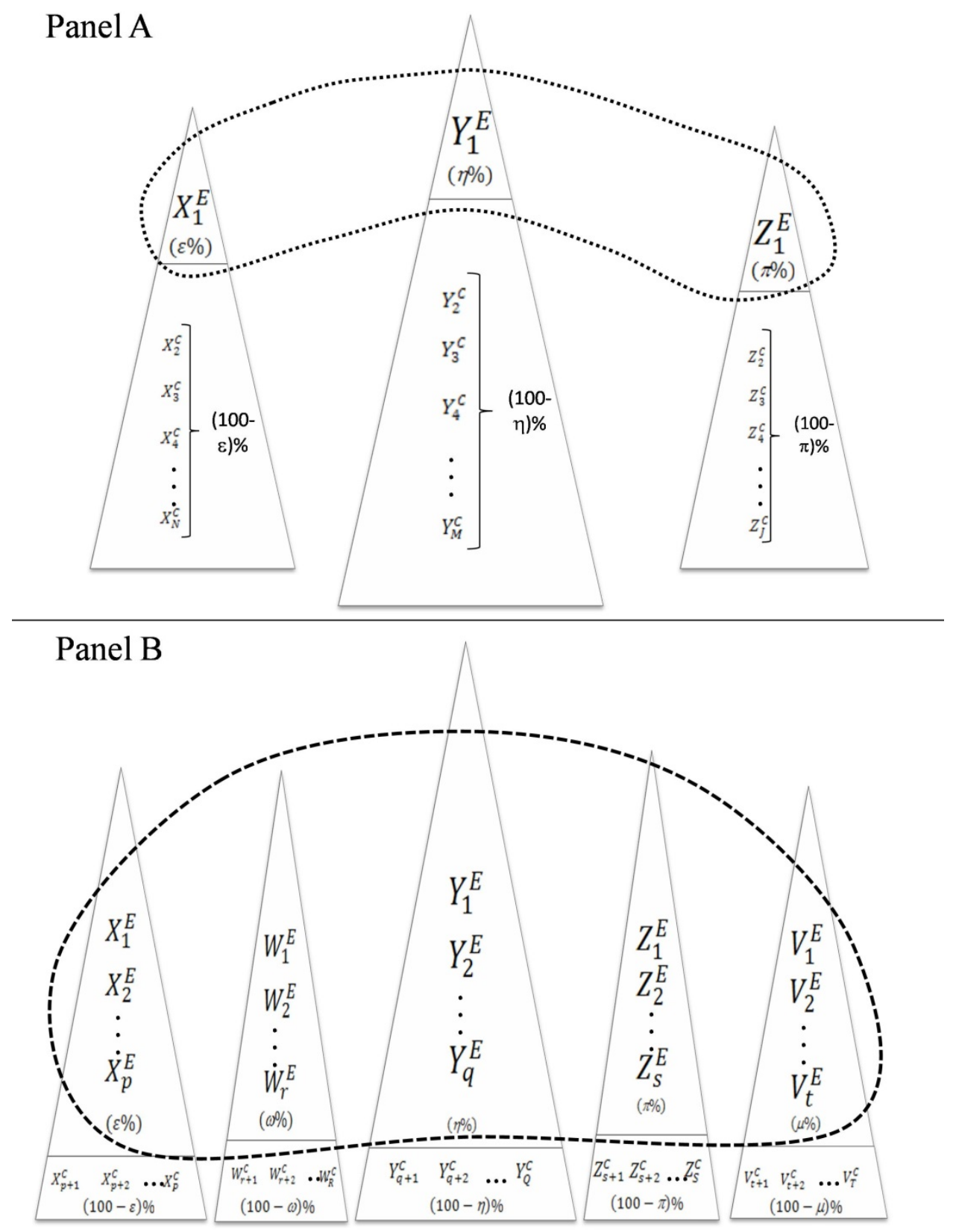

Figure 1. Dominant network. 


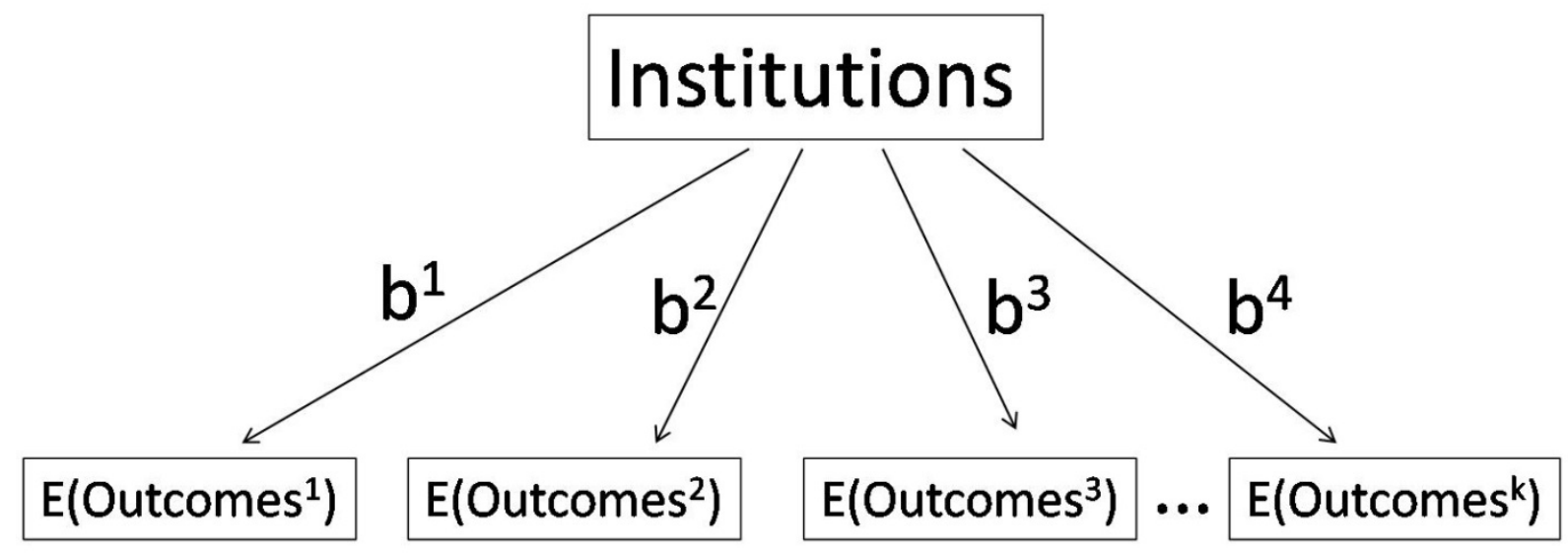

Figure 2. Expected outcomes given a set of formal institutions. 

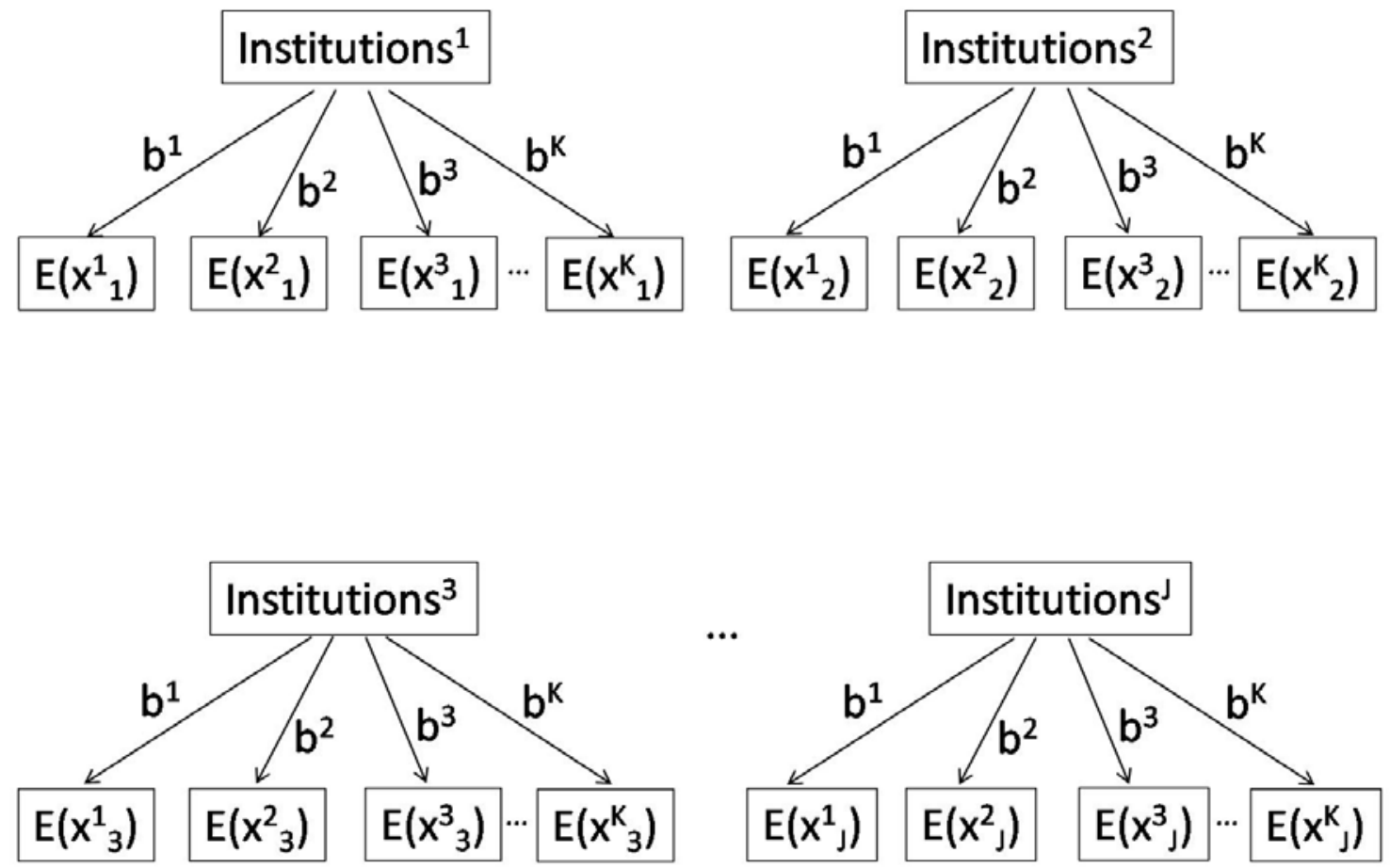

where $\mathrm{x}_{\mathrm{j}}^{\mathrm{k}}=$ outcomes

Figure 3. Expected outcomes from all possible formal institutions. 

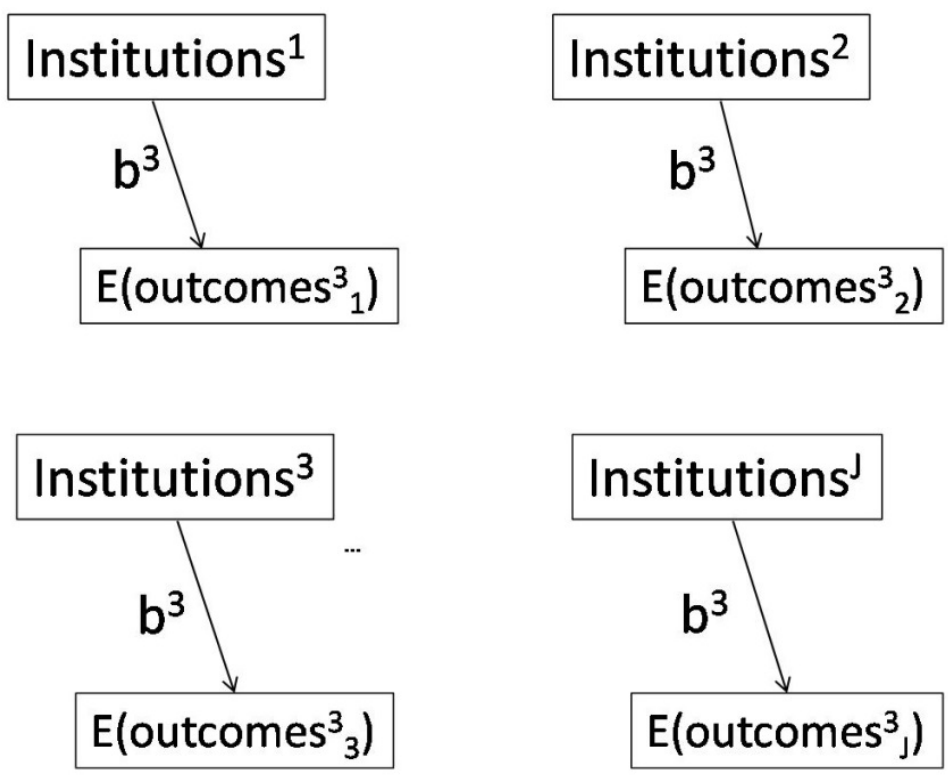

Figure 4. Choice of formal institutions given beliefs. 


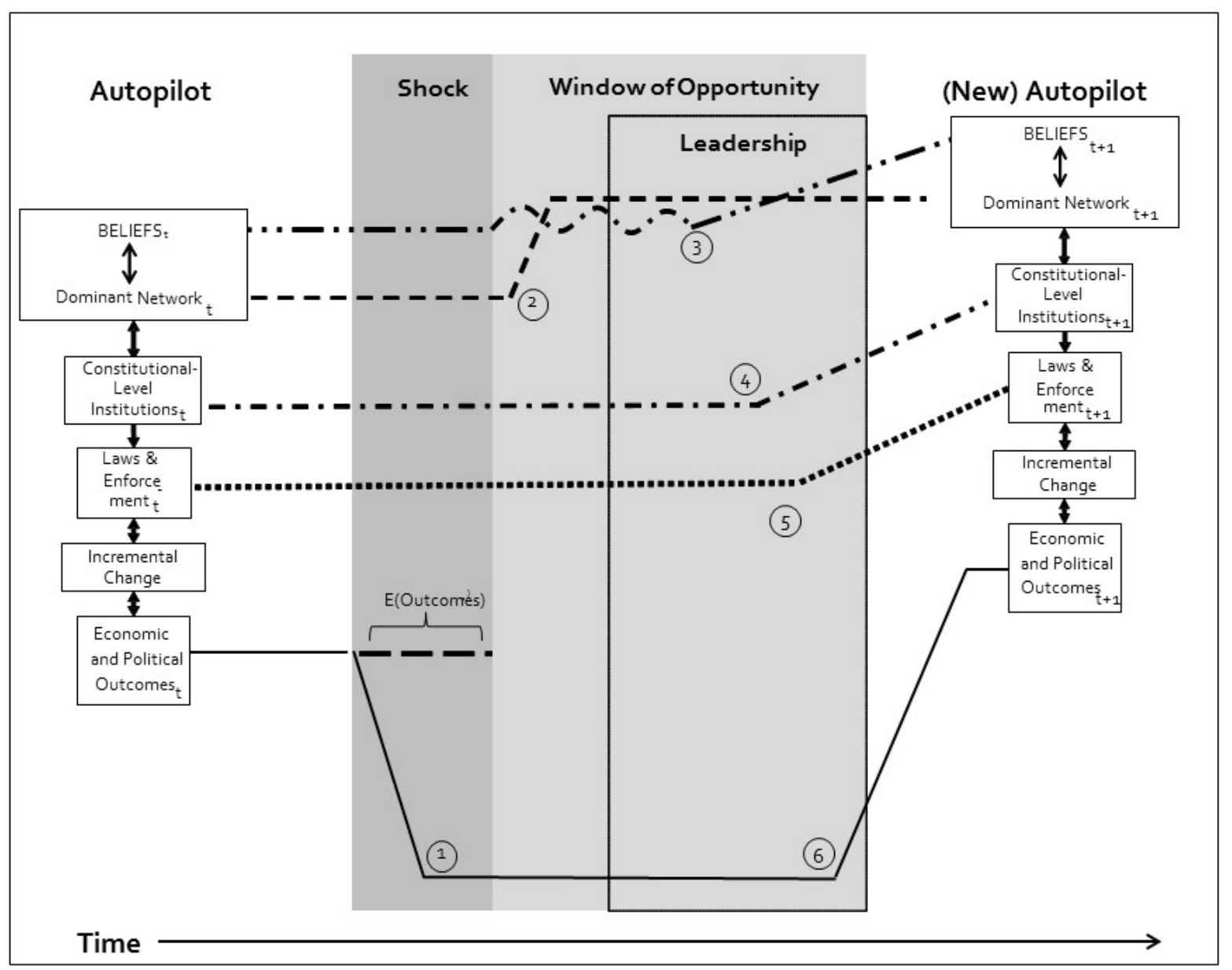

Figure 5. Autopilot and critical transitions. 